\title{
ER-Targeting Cyanine Dye as an NIR Photoinducer to Efficiently Trigger Photoimmunogenic Cancer Cell Death
}

He Ma,${ }^{\dagger}$ Yang Lu, ${ }^{\dagger}$ Zhibin Huang, ${ }^{\dagger}$ Saran Long, ${ }^{\dagger}, \|$ Jianfang Cao, ${ }^{\dagger}$ Zhen Zhang, ${ }^{\dagger}$ Xiao Zhou, ${ }^{\dagger}$ Chao Shi, ${ }^{\dagger}$ Wen Sun, ${ }^{\dagger, \|}$ Jianjun Du, ${ }^{\dagger, \|}$ Jiangli Fan, ${ }^{\dagger}, \|$ and Xiaojun Peng ${ }^{\dagger},\|\|$

${ }^{\dagger}$ State Key Laboratory of Fine Chemicals, Dalian University of Technology, Dalian 116024, China

"School of Chemical Engineering, Dalian University of Technology, Panjin Campus, Panjin 124221, China

"State Key Laboratory of Fine Chemicals and Shenzhen Research Institute, Dalian University of Technology, Dalian 116024, China

*Correspondence author. Email: pengxj@dlut.edu.cn; 


\section{Figure S1-S14}

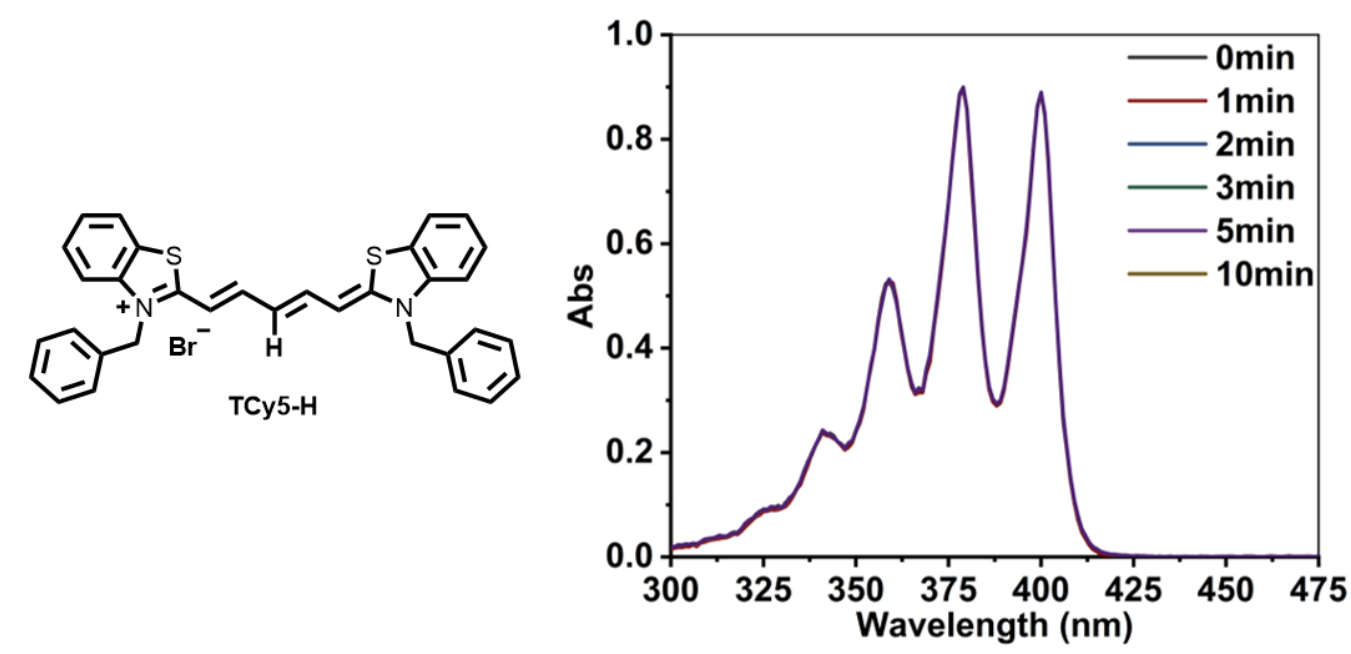

Figure S1. Time-dependent UV-vis absorption spectra recording 9,10-anthracenediylbis(methylene)-dimalonic acid (ABDA) over TCy5-H under $10 \mathrm{~mW} \mathrm{~cm}$-2 $^{-2}$ LED light irradiation in water.

$\mathbf{a}$

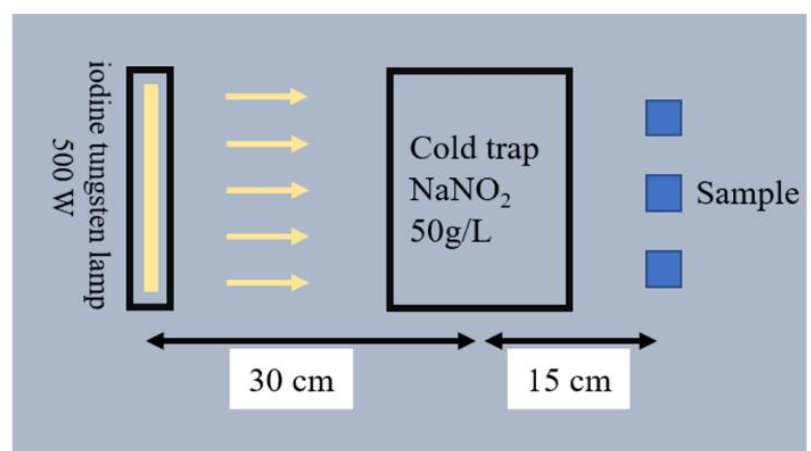

b

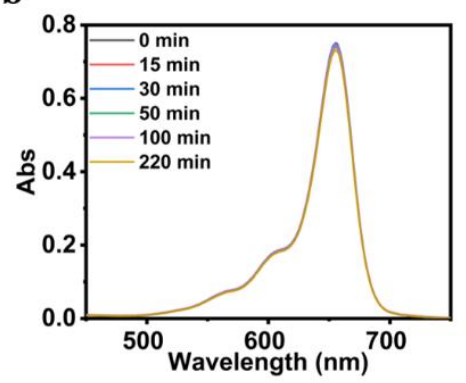

c

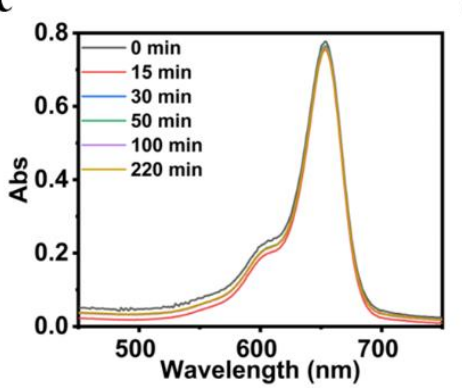

d

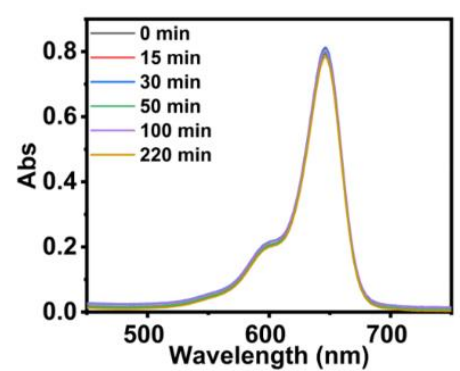

Figure S2. (a) The sketch for photostability test. UV-vis spectra of (b) TCy5-Ph-CF 3 , (c) TCy5$\mathrm{Ph}-2 \mathrm{~F}$, and (d) TCy5-Ph-3F at absorption maximum against exposure time. 


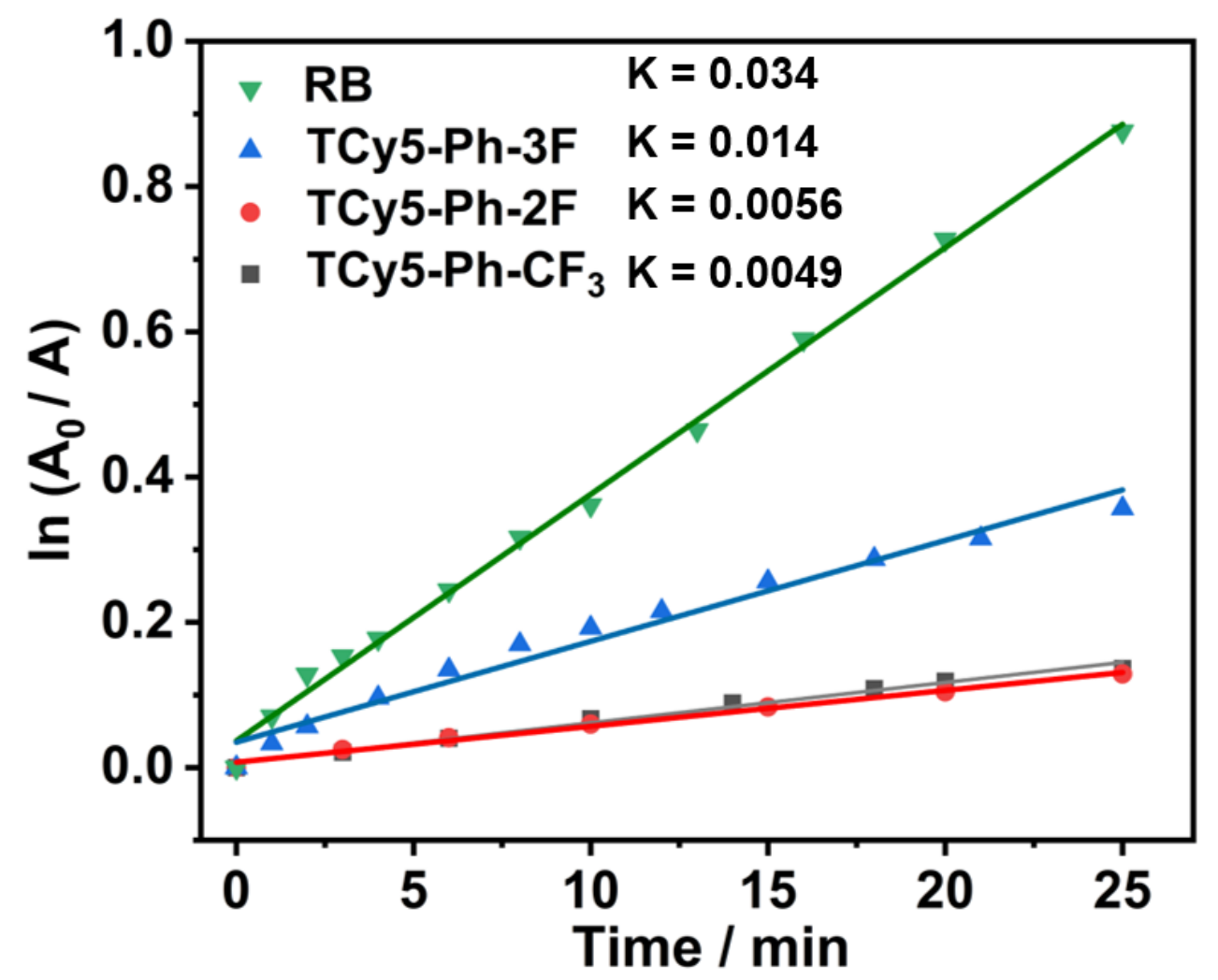

Figure S3. The linear fit of RB, TCy5-Ph-CF 3 , TCy5-Ph-2F, and TCy5-Ph-3F based on absorbance of ABDA at $380 \mathrm{~nm}$ in aqueous solutions for different durations with $1 \mathrm{~mW}$ LED light $(550 \mathrm{~nm}$ for $\mathrm{RB}, 660 \mathrm{~nm}$ for TCy5).

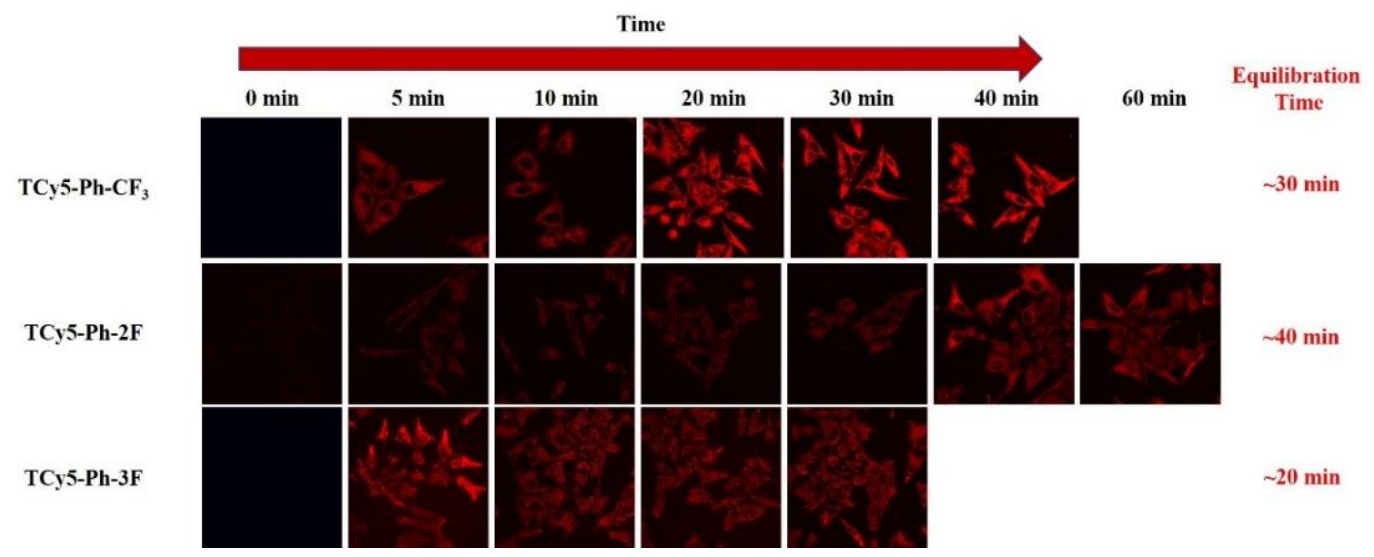

Figure S4. Cellular uptake of TCy5 in MCF7 cells. Emissions are collected at $650-730 \mathrm{~nm}\left(\lambda_{\mathrm{ex}}=\right.$ $640 \mathrm{~nm})$. 


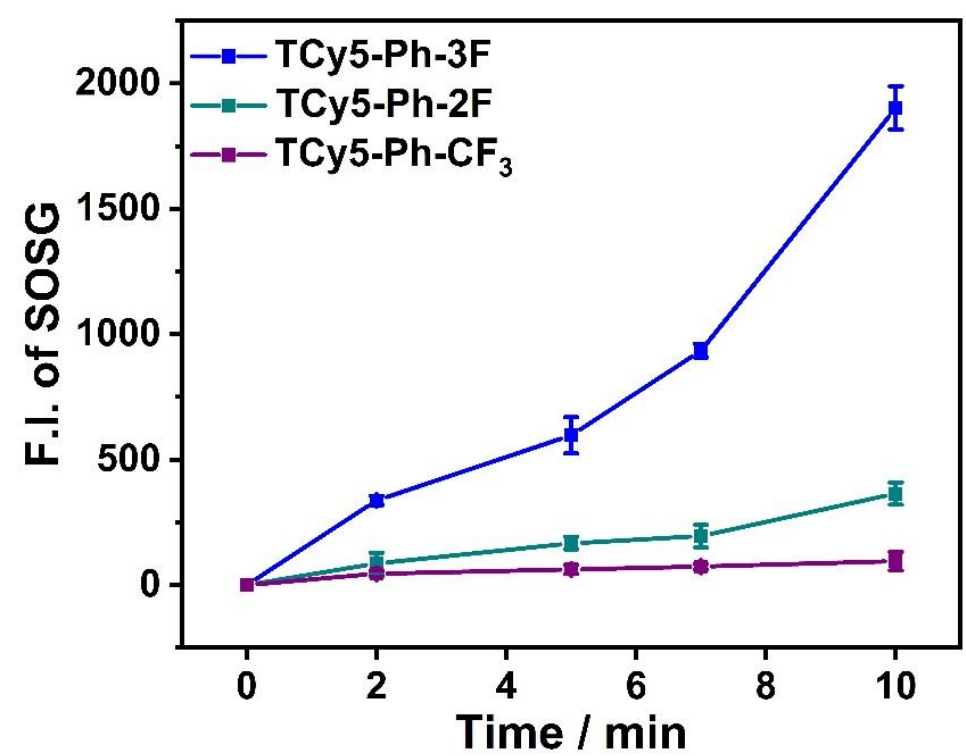

Figure S5. the fluorescence intensity of SOSG in MCF7 treated with TCy5

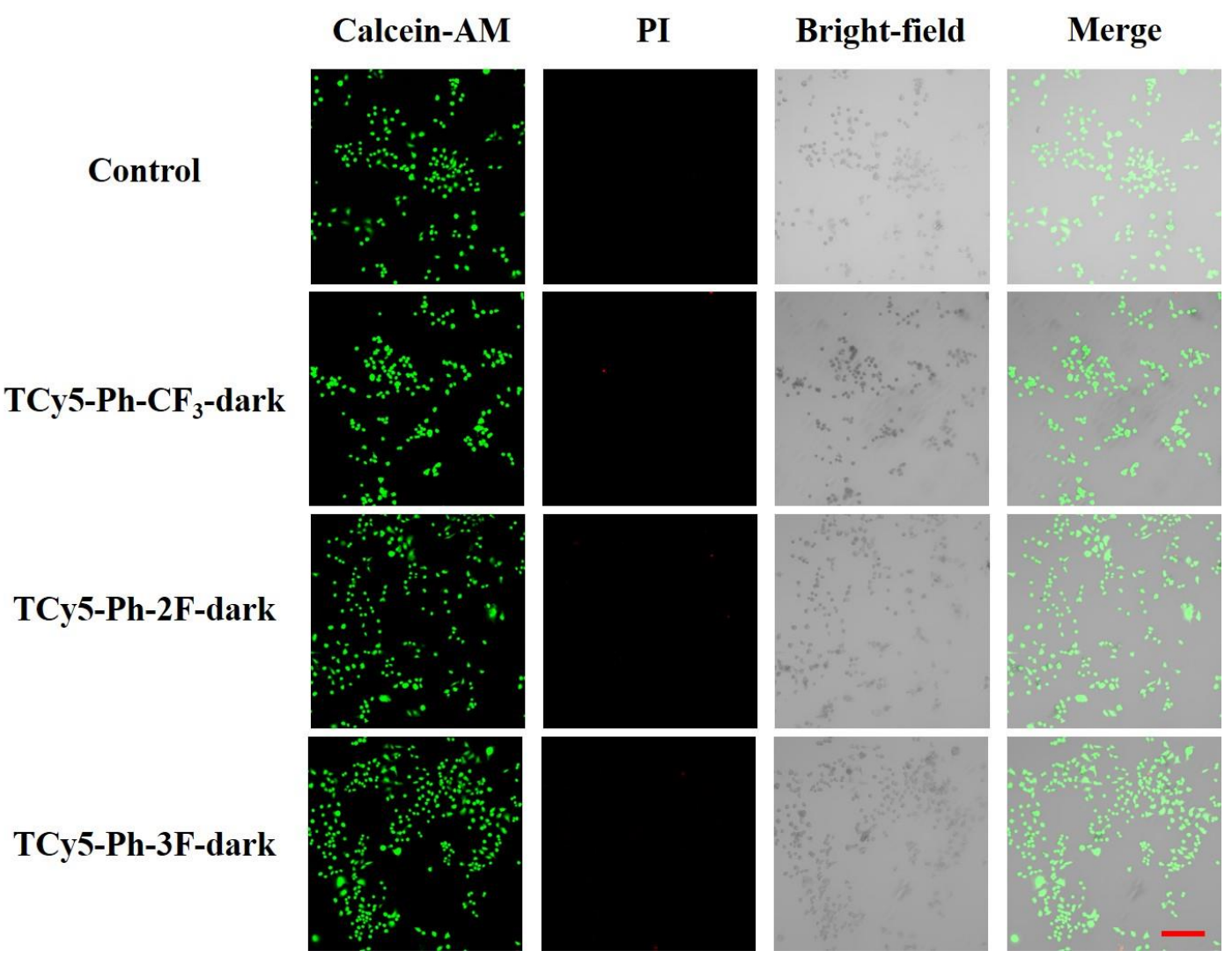

Figure S6. Evaluation of dark toxicity using probe Calcein AM/Propidium Iodide (PI) in MCF7 cells treated with compound TCy5 without light irradiation. For Calcein AM and PI, emissions are collected at $505-545 \mathrm{~nm}$ and $600-700 \mathrm{~nm}\left(\lambda_{\mathrm{ex}}=488 \mathrm{~nm}\right)$, respectively. Scale bar $=200 \mu \mathrm{m}$. 


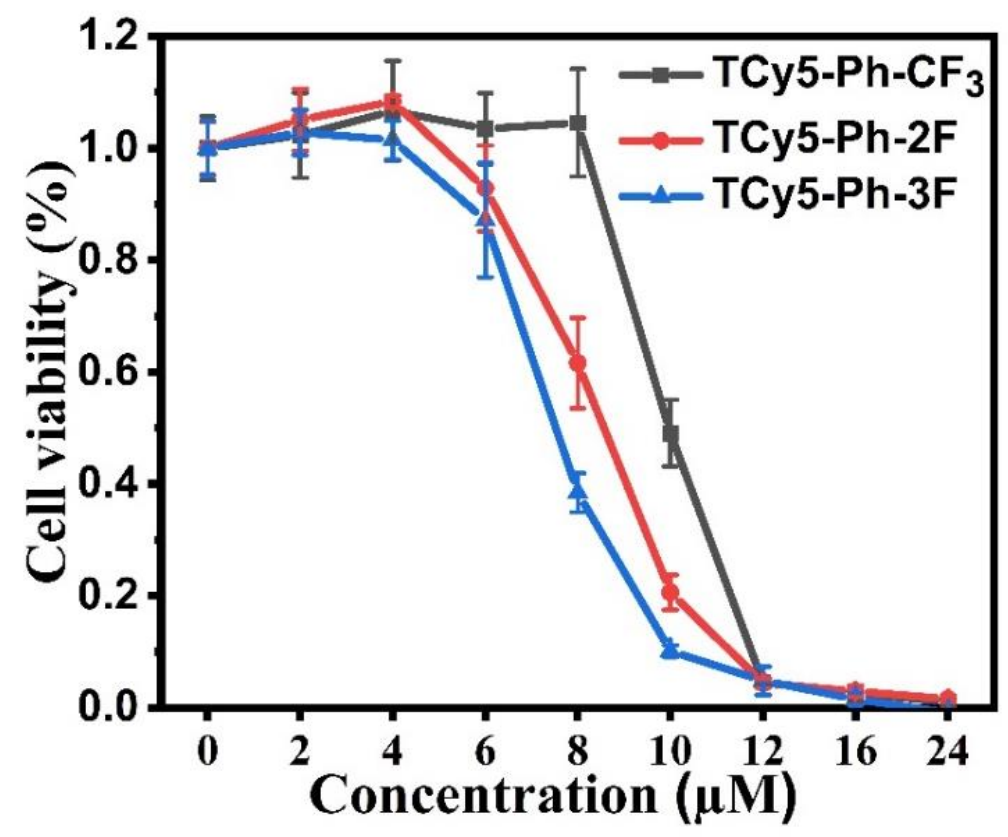

Figure S7. The dark cytotoxicity of TCy5 with MCF7 cells

Table S1. IC 50 values of MCF7 treated with TCy5 in normoxia

\begin{tabular}{|l|c|c|}
\hline \multirow{2}{*}{} & \multicolumn{2}{|c|}{$\mathrm{IC}_{50}(\mu \mathrm{M})$} \\
\cline { 2 - 3 } & Dark & Light \\
\hline TCy5-Ph-CF & 6.05 & 1 \\
\hline TCy5-Ph-2F & 5.20 & 0.5 \\
\hline TCy5-Ph-3F & 4.73 & 0.125 \\
\hline
\end{tabular}
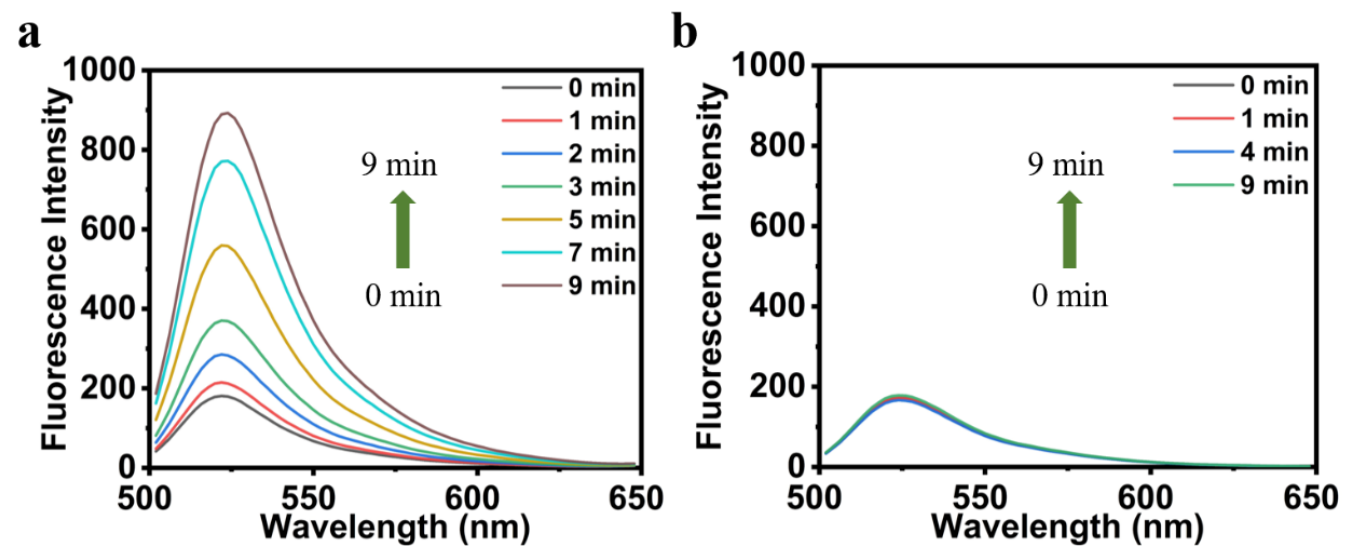

Figure S8. Fluorescence intensity of DHR123 in TCy5-Ph-3F solutions $(10 \mu \mathrm{M})$ irradiated for different durations with $660 \mathrm{~nm}$ light irradiation $\left.(10 \mathrm{~mW} \mathrm{~cm})^{-2}\right)$. In aqueous solutions, the fluorescence intensity of DHR123 at $526 \mathrm{~nm}$ is recorded upon different irradiation time to character the photosensitizing process. a (TCy5-Ph-3F and DHR123, $660 \mathrm{~nm}$ ), b (only DHR123, $660 \mathrm{~nm}$ ). 


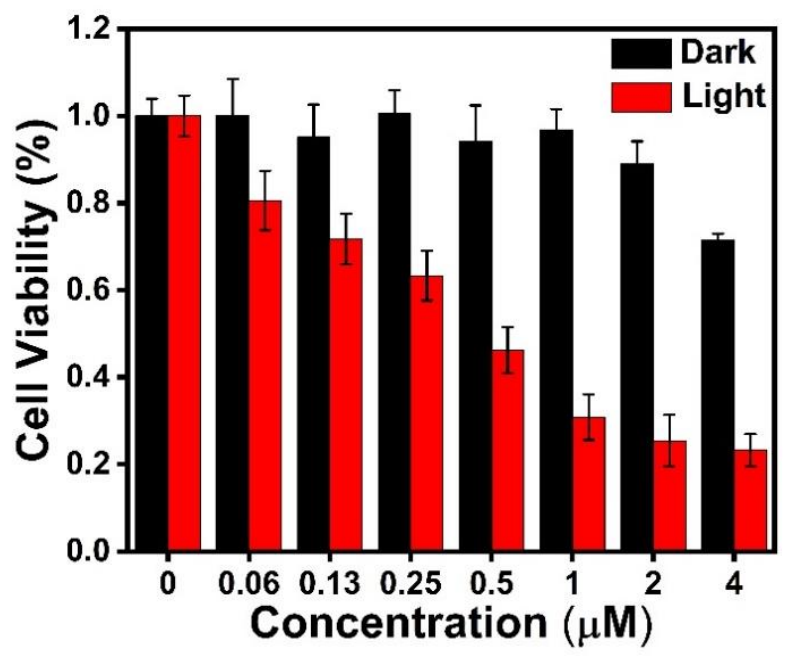

Figure S9. MTT assay of MCF7 cells treated with TCy5-Ph-3F in hypoxia

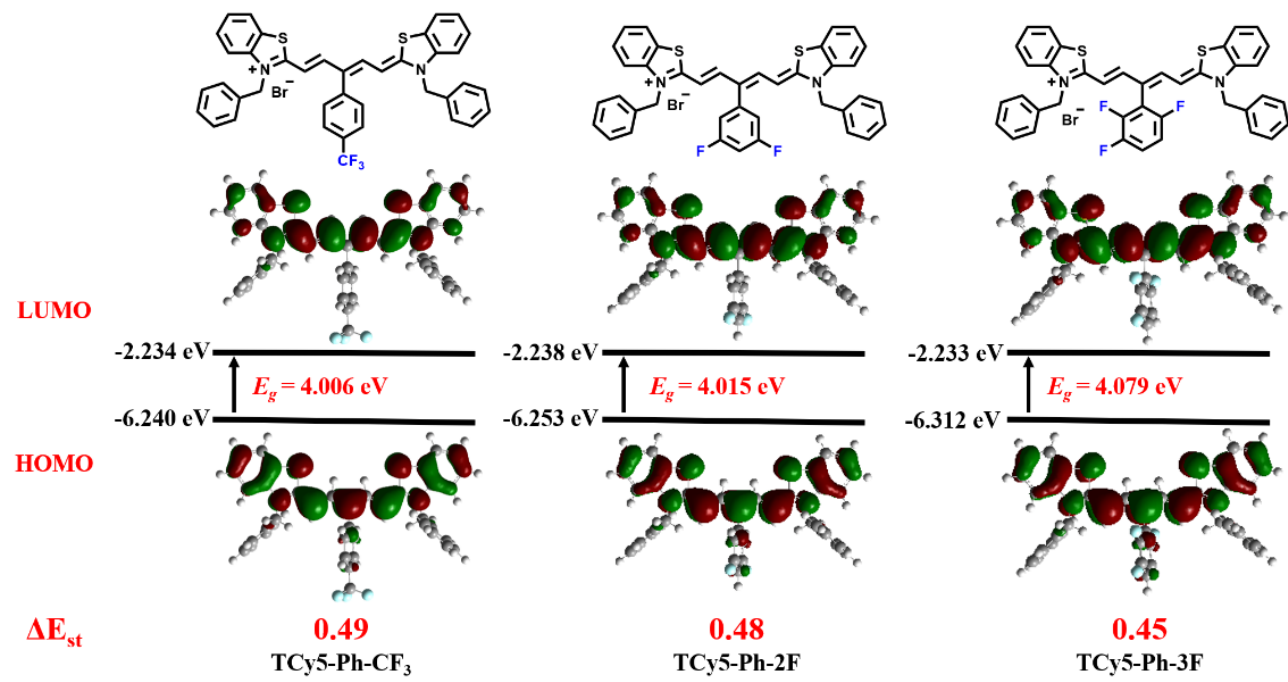

Figure S10. The HOMO-LUMO distribution of TCy5 was calculated by TD-DFT (Gaussian $09 / \mathrm{M} 062 \mathrm{X} / 6-31+\mathrm{G}(\mathrm{d}, \mathrm{p})$ ). based on the optimized ground-state geometries (water was used as solvent in the calculation).
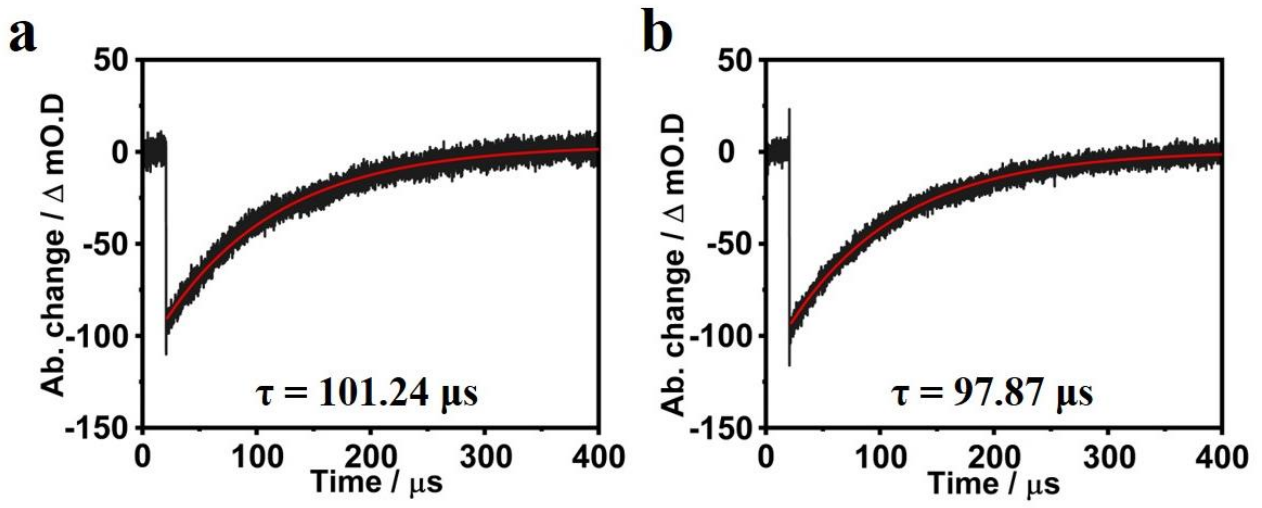

Figure S11. Nanosecond time-resolved transient absorption decay trace of (a) TCy5-Ph- $\mathrm{CF}_{3}$ and (b) TCy5-Ph-2F at $660 \mathrm{~nm}$ upon nanosecond pulsed laser excitation $\left(\lambda_{\mathrm{ex}}=609 \mathrm{~nm}\right)$. 
a

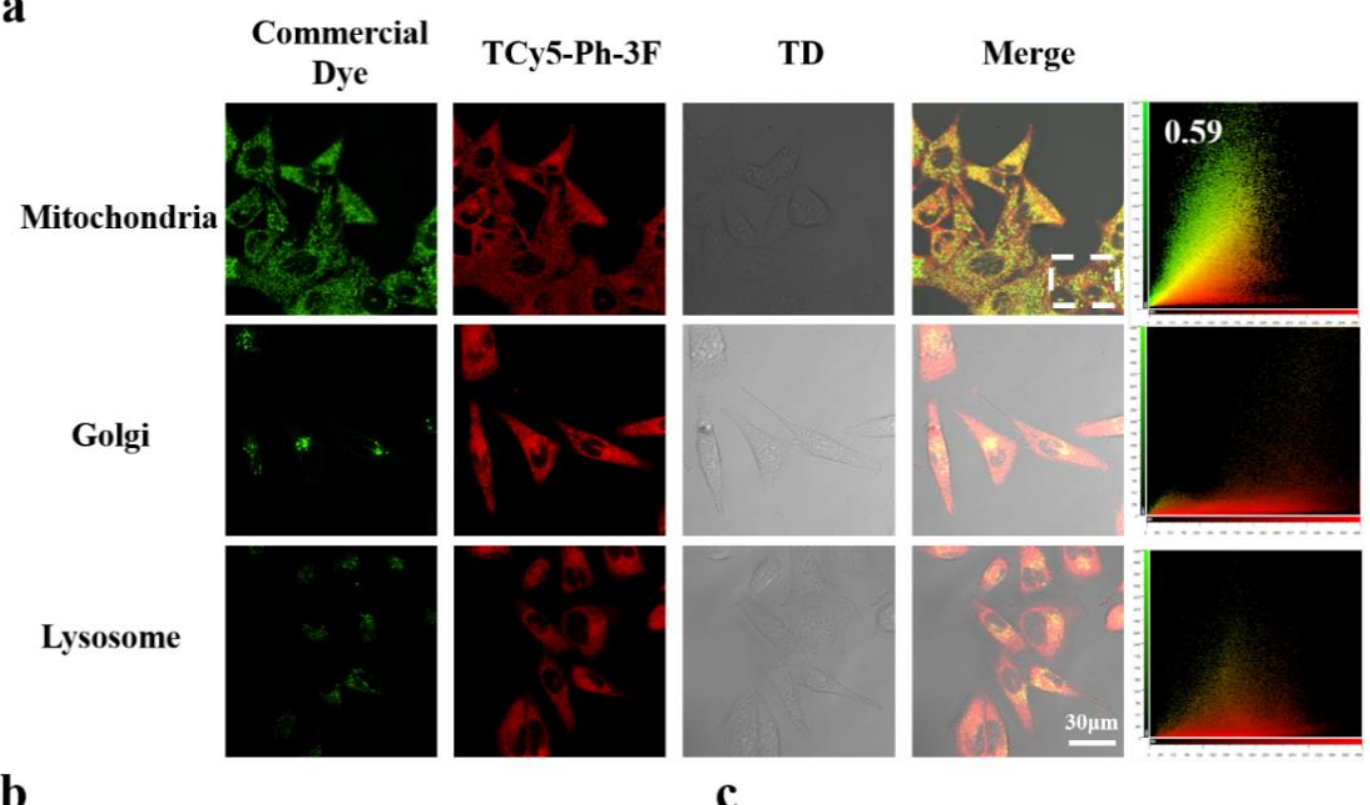

b
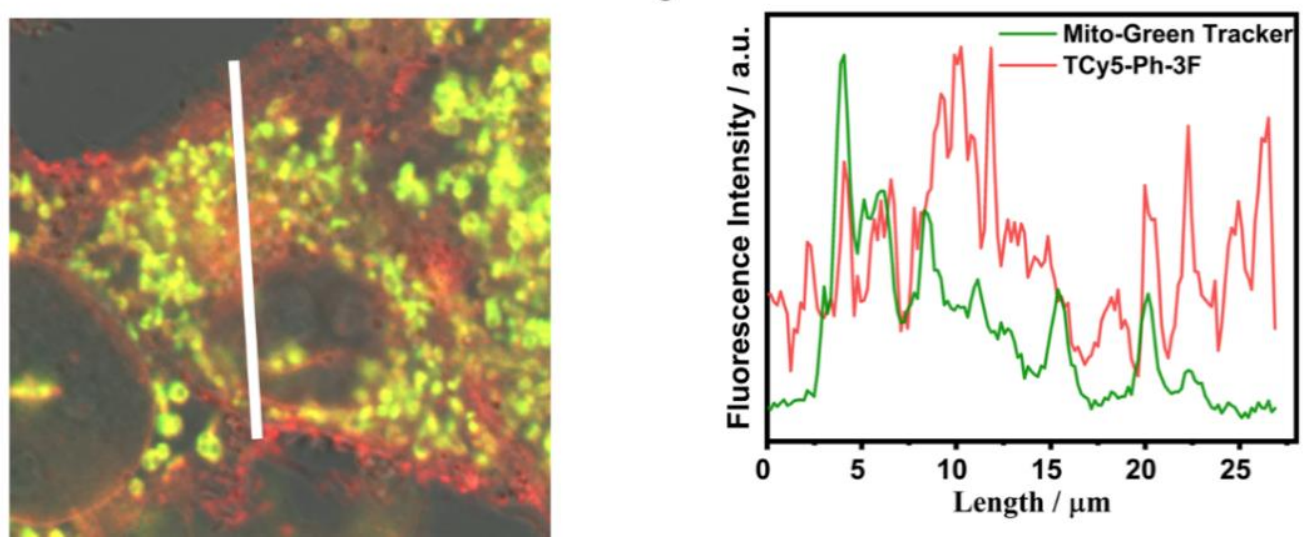

Figure S12. (a) Fluorescence imaging of MCF7 cells labeled with TCy5-Ph-3F and their colocalization with Mito-, Golgi- and Lyso-tracker Green, respectively. $\lambda_{\mathrm{ex}}=488 \mathrm{~nm}, \lambda_{\mathrm{em}}=500$ $580 \mathrm{~nm}, \lambda_{\mathrm{ex}}=640 \mathrm{~nm}, \lambda_{\mathrm{em}}=650-730 \mathrm{~nm}$. Scale bar $=30 \mu \mathrm{m}$. (b) the enlargement of part of (a). (c) The line-plot graphs exhibit the fluorescence intensity profiles of the Mito-Green-Tracker (green) and TCy5 (red) along the white lines in the CLSM images of (b). 


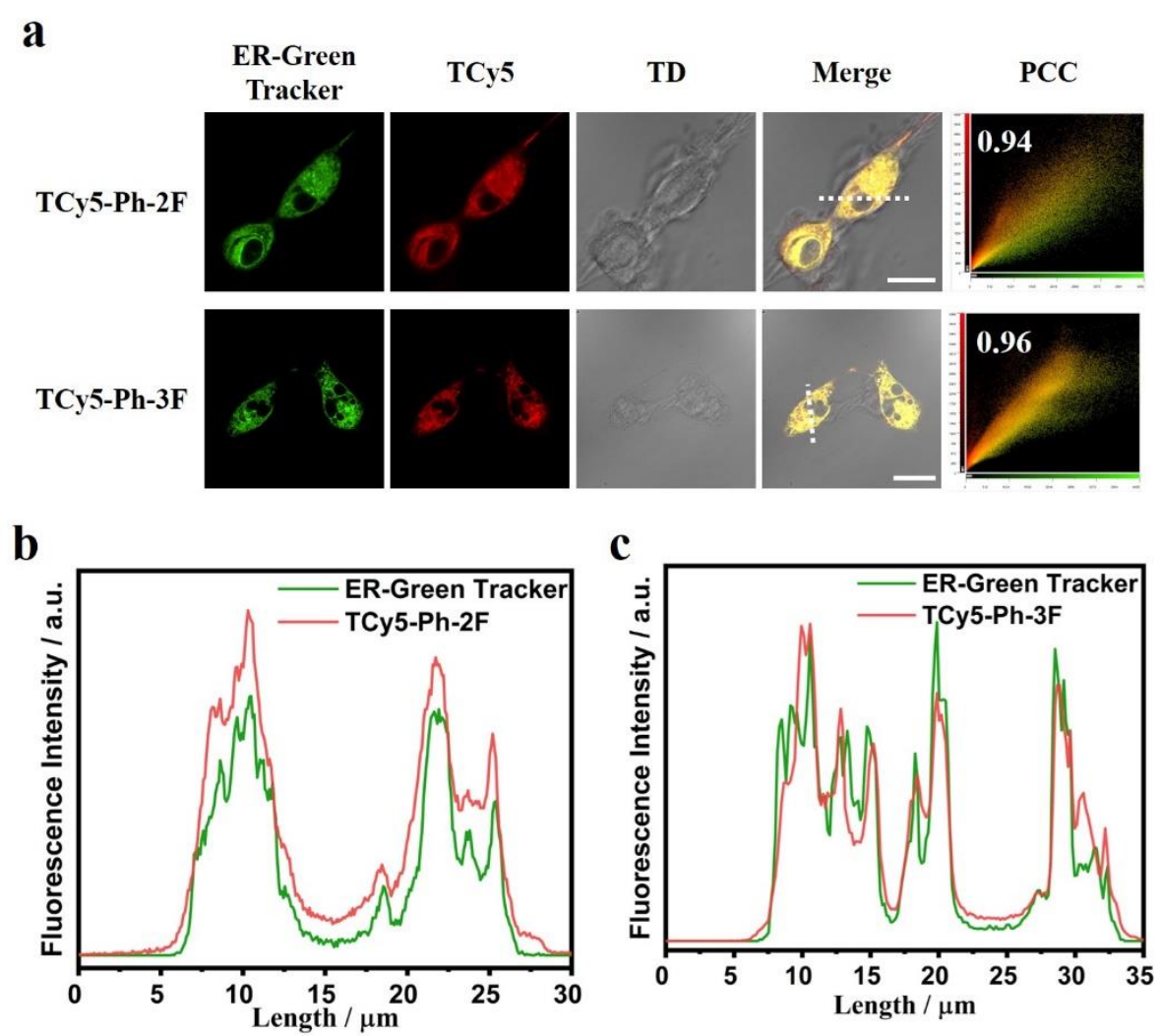

Figure S13. Spontaneous ER localizability of the TCy5-Ph-2F and TCy5-Ph-3F in $4 \mathrm{~T} 1$ cells. (a) Representative CLSM merged images of 4T1 cells treated with $0.5 \mu \mathrm{M}$ of each ER-Green-Tracker (Green) and $1 \mu \mathrm{M}$ of TCy5 (Red) for $30 \mathrm{~min}$. Correlation of Pearson's correlation coefficients (PCC) of the TCy5/ER-Green-Tracker signal overlap observed in the CLSM images, and colocalization areas are in yellow. (b)-(c) The line-plot graphs exhibit the fluorescence intensity profiles of the ERGreen-Tracker (green) and TCy5 (red) along the white dotted lines indicated in the CLSM images of (a). (b) and (c) are associated with TCy5-Ph-2F and TCy5-Ph-3F, respectively. Scale bar $=20$ $\mu \mathrm{m}$. 


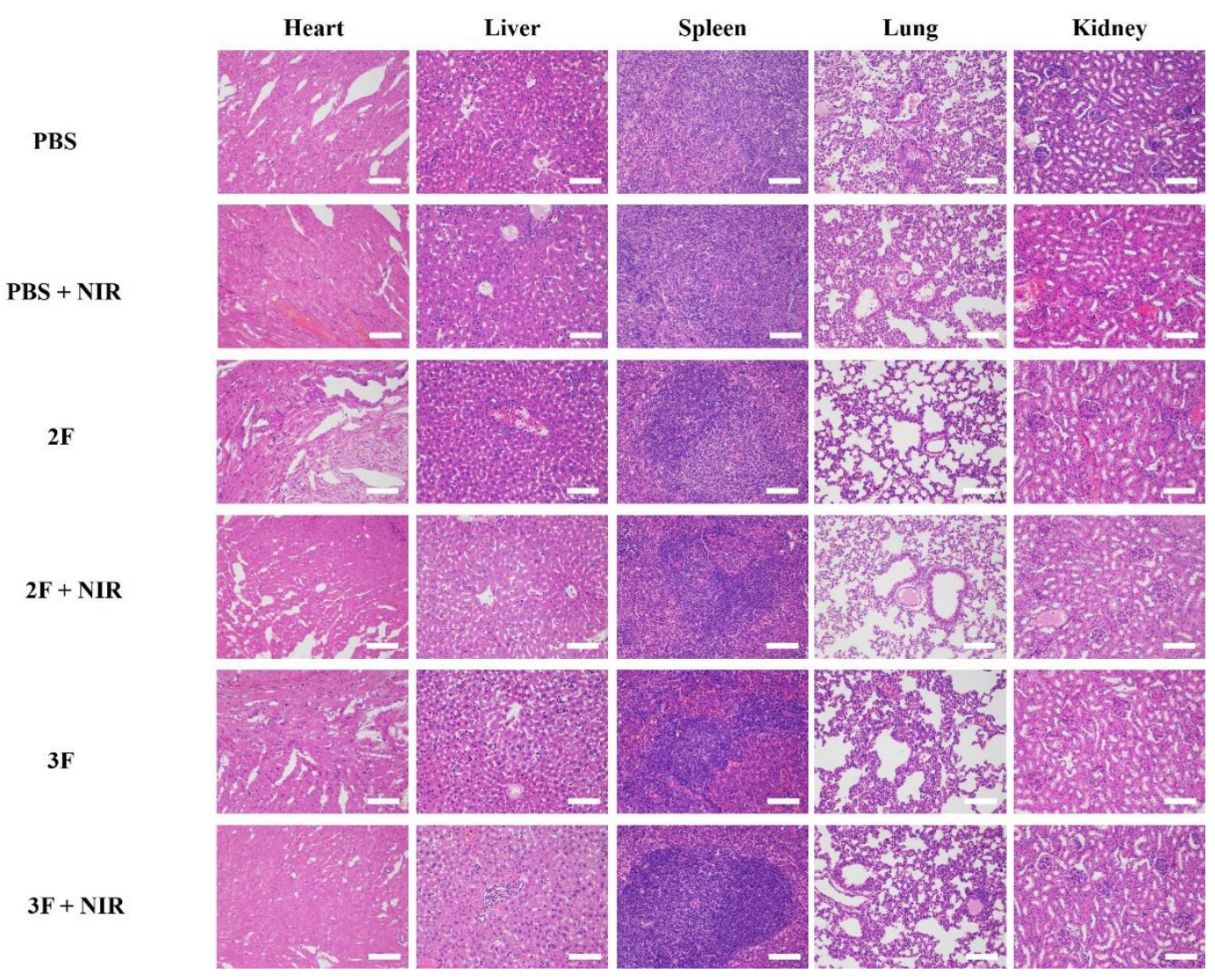

Figure S14. Typical images of H\&E-stained lung, heart, spleen, liver, and kidney from mice after different treatments of Balb/C mice: 1) PBS, 2) PBS + light 3) TCy5-Ph-2F, 4) TCy5-Ph-2F + light, 5) TCy5-Ph-3F, 6) TCy5-Ph-3F + light. Scale bar $=100 \mu \mathrm{m}$. 


\section{General Information}

In this report, the general chemicals including 3-(4,5-dimethylthiazol-2-yl)-2,5diphenyltetrazolium bromide (MTT), hypericin were purchased from Energy Chemical Co., and all the solvents were of analytic grade. Flash column chromatography was performed with silica gel (200-300 mesh) and dichloromethane/methanol was used as eluent. Singlet Oxygen Sensor Green (SOSG) was obtained from life technologies. All the other solvents and reagents used in this study were of analytical grade. NMR spectra were detected by Bruker Avance III 500 spectrometer. Chemical shift $(\delta)$ was reported as ppm in DMSO- $d_{6}$ with TMS as the internal standard. The mass spectrum was recorded on Agilent 6224 TOF LC/MS instruments. Absorption and emission spectra for three TCy5 were performed with a Lambda 35 UV-visible spectrophotometer (PerkinElmer) and a VAEIAN CARY Eclipse fluorescence spectrophotometer (Serial No. FL0812-M018), respectively. Fluorescence quantum yield was obtained with the HAMAMATSU absolute fluorescence quantum yield spectrometer (Serial No. C11347). Nanosecond time-resolved transient absorption spectra were recorded on a LP980 laser flash photolysis spectrometer (Edinburgh Instruments Ltd.) in combination with a Nd:YAG laser (Surelite I-10, Continuum Electro-Optics, Inc.). Confocal laser scanning microscope (CLSM) images were performed on Olympus FV3000 confocal laser scanning microscope. For solution and in vitro tests, stock solution of TCy5 in DMSO (1 mM and $10 \mathrm{mM}$ ) was prepared. For in vivo test, TCy5 was dissolved in saline solution. 


\section{Analysis test procedure}

\section{Singlet oxygen $\left({ }^{1} \mathrm{O}_{2}\right)$ detection}

The singlet oxygen was measured by specificity capture agent, 9,10anthracenedipropanoic acid (ABDA). The absorbance of ABDA at $380 \mathrm{~nm}$ was adjusted to about 1.0 in water $(3 \mathrm{~mL})$. Then, $10 \mu \mathrm{M}$ TCy5 was added to this cuvette, which was irradiated with $660 \mathrm{~nm}$ monochromatic light $\left(10 \mathrm{~mW} \mathrm{~cm}^{-2}\right)$ for various time. The absorption spectra were measured immediately.

\section{Procedure for ${ }^{1} \mathrm{O}_{2}$ Quantum Yield Measurement ${ }^{1}$}

In $3 \mathrm{~mL}$ of the ultrapure water, $10 \mu \mathrm{M}$ of TCy 5 was incubated for $1 \mathrm{~min}$, and the absorbance of ABDA at $380 \mathrm{~nm}$ was adjusted to about 1.0 in water. UV-vis absorption spectra were recorded after the probe was exposed to $660 \mathrm{~nm}$ monochromatic light with a power density of $1 \mathrm{~mW} / \mathrm{cm}^{2}$ for various time. The ${ }^{1} \mathrm{O}_{2}$ quantum yield was measured using Rose Bengal (RB) with $550 \mathrm{~nm}$ monochromatic light as the reference photosensitizer and calculated using the following equation:

$$
\Phi_{\text {probe }}=\Phi_{\mathrm{RB}} \frac{K_{\text {probe }} \mathrm{A}_{\mathrm{RB}}}{K_{\mathrm{RB}} A_{\text {probe }}}
$$

where $K_{\text {probe }}$ and $K_{\mathrm{RB}}$ were the decomposition rate constants of ABDA in the presence of the probe and $\mathrm{RB}$, respectively. $\Phi_{\mathrm{RB}}$ was the ${ }^{1} \mathrm{O}_{2}$ quantum yield of $\mathrm{RB}\left(\Phi_{\mathrm{RB}}=0.75\right.$ in water). The natural logarithm of the absorbance ratio $\left(\mathrm{A}_{0} / \mathrm{A}\right)$ of $\mathrm{ABDA}$ at $380 \mathrm{~nm}$ was plotted against irradiation time and the slope is regarded as the decomposition rate.

\section{Superoxide anion radical $\left(\mathrm{O}_{2}{ }^{--}\right)$detection}

Dihydrorhodamine 123 (DHR123) was used as the $\mathrm{O}_{2}{ }^{--}$indicator, which can be converted to Rhodamine 123 in the presence of $\mathrm{O}_{2}{ }^{--}$. TCy5-Ph-3F and DHR123 were prepared as $10 \mu \mathrm{M}$ and $10 \mu \mathrm{M}$ in water, respectively. After blending well, the cuvette was irradiated to $660 \mathrm{~nm}\left(10 \mathrm{~mW} \mathrm{~cm}^{-2}\right)$ monochromatic light for different time, and the fluorescence spectra were observed immediately after each irradiation. As control, DHR123 aqueous solution without photosensitizers was subjected to irradiation $\left(\lambda_{\mathrm{ex}}=\right.$ $488 \mathrm{~nm})$. 


\section{Cell incubation}

MCF7 cells, 4T1 cells were purchased from the Institute of Basic Medical Sciences (IBMS) of the Chinese Academy of Medical Sciences and cultured with Dulbecco's modified Eagle's medium (DMEM, Invitrogen) containing $10 \%$ fetal bovine serum (Invitrogen) and $1 \%$ antibiotics (penicillin/streptomycin, $100 \mathrm{U} \mathrm{mL}^{-1}$ ) in an atmosphere of $\mathrm{CO}_{2} /$ air $=5 \% / 95 \%$ at $37{ }^{\circ} \mathrm{C}$.

\section{Cytotoxicity assay}

The cytotoxicity in the presence or absence of light was evaluated by reducing MTT (3-(4,5)-dimethylthiazol-2-yl)-3,5-diphenyltetrazolium bromide) to formazan crystals with mitochondrial dehydrogenases. MCF7 cells were seeded in a 96-well plate with a concentration of $1 \times 10^{5}$ cells per mL in $100 \mathrm{~mL}$ DMEM medium (containing $10 \%$ FBS) incubated at $37{ }^{\circ} \mathrm{C}$ for $24 \mathrm{~h}$. For the photo-cytotoxicity evaluation, different concentrations of TCy5 from 0 to $2 \mu \mathrm{M}$ in DMEM medium were added to the wells of cells, respectively. Then, the cells were further incubated for $1 \mathrm{~h}$ under normoxic conditions, respectively. Subsequently, the cells were subjected to $660 \mathrm{~nm}$ light (10 $\left.\mathrm{mW} / \mathrm{cm}^{2}, 10 \mathrm{~min}\right)$. Then the cells were further incubated for $24 \mathrm{~h}$ at $37^{\circ} \mathrm{C}$. Next, MTT solution $(5 \mathrm{mg} / \mathrm{mL})$ was added in DMEM to each well following incubated the cells for $4 \mathrm{~h}$, the solution in each well was removed out carefully, and added $100 \mu \mathrm{L}$ DMSO to each well. The plate was then shaken for $10 \mathrm{~min}$ and the absorbance was determined on a microplate reader (Thermo Fisher Scientific) at $570 \mathrm{~nm}$ and $630 \mathrm{~nm}$. The viability was expressed as a percent of the controlled one using the following equation:

$$
\text { Cell viability }(\%)=\frac{\mathrm{OD}_{\text {dye570 }}-\mathrm{OD}_{\text {dye630 }}}{\mathrm{OD}_{\text {control570 }}-O D_{\text {control630 }}} \times 100 \%
$$

For dark toxicity measurement of TCy5, the light irradiation was canceled and the other steps were same.

\section{Laser flash photolysis}

Nanosecond time-resolved transient absorption spectra were recorded on a LP980 laser flash photolysis spectrometer (Edinburgh Instruments Ltd.) in combination with a Nd:YAG laser (Surelite I-10, Continuum Electro-Optics, Inc.). Samples in nitrogen atmosphere were excited by a $555 \mathrm{~nm}$ laser pulse $(1 \mathrm{~Hz}, 100 \mathrm{~mJ}$ per pulse, fwhm $\approx 7$ 
ns) at room temperature. The absorbances of TCy5-Ph-3F was lower than 0.5 OD at $588 \mathrm{~nm}$ in $1 \mathrm{~cm}$ path length quartz cuvettes.

\section{Computations details of B3LYP}

Density Functional Theory (DFT) Calculations: The DFT and TD-DFT calculations were performed using the Gaussian09 program to optimize the molecular geometries of $\mathrm{S}_{0}$ state, $\mathrm{S}_{1}$ state and $\mathrm{T}_{1}$ state (the atomic standard orientations after geometry optimization of ground state and excited state have been given in supporting information). Becke's three-parameter hybrid exchange functions with Lee-Yang-Parr gradient-corrected correlation functional (B3LYP functional) is the more reasonable choice to be in good accordance with the experimental results, ${ }^{2}$ and used in both the DFT and TD-DFT methods in the sequential work. The 6-31G(d,p) basis set was chosen as the basis set throughout, which is an appropriate basis set for such organic compound. ${ }^{3}$

\section{Femtosecond Transient Absorption Spectra}

The femtosecond transient absorption spectra of compound TCy5-Ph-3F was measured by a home-made ultrafast pump-probe setup. The pulse duration was 30 fs. The wavelength of the pump beam was chosen to be $380 \mathrm{~nm}$. The used concentration of samples was $50 \mu \mathrm{M}$ for TCy5-Ph-3F in DCM at room temperature. Measurements were performed in $1 \mathrm{~mm}$ quartz cuvettes.

\section{Evaluation of Glucose-Regulated Protein 78 (GRP78)}

MCF7 cells were divided into three groups and incubated with: 1, DMEM; 2, TCy5$\mathrm{Ph}-2 \mathrm{~F}(1 \mu \mathrm{M})$; 3, TCy5-Ph-3F $(1 \mu \mathrm{M})$ for $1 \mathrm{~h}$, then the cells were irradiated by $660 \mathrm{~nm}$ LED $\left(5 \mathrm{~mW} / \mathrm{cm}^{-2}, 5 \mathrm{~min}\right)$. After 4 hours, the cells were washed with pre-cooling PBS, fixed with $4 \%$ paraformaldehyde on $4^{\circ} \mathrm{C}$ for $20 \mathrm{~min}$, and permeated before treated with blocking reagent $(10 \%$ bovine serum in PBS). Then cells were stained with GRP78 Rabbit Polyclonal Antibody overnight at $4^{\circ} \mathrm{C}$. After washed with buffer, cells were stained with the Alexa Fluor 488-labeled Goat Anti-Rabbit $\operatorname{IgG}(\mathrm{H}+\mathrm{L})$ for $1 \mathrm{~h}$ in the dark and then washed with buffer three times. Finally, the cells incubated with Hoechst 33342. The expression levels of GRP78 in each treated cancer cells were visualized by the GRP78 immunofluorescence using CLSM. For Hoechst 33342, emissions were 
collected at 430-470nm $\left(\lambda_{\mathrm{ex}}=405 \mathrm{~nm}\right)$, and for GRP78-Alexa, emissions were collected at $500-580 \mathrm{~nm}\left(\lambda_{\mathrm{ex}}=488 \mathrm{~nm}\right)$.

\section{Visualization of High Mobility Group Protein (HMGB1)/Calreticulin by confocal microscopy.}

The immunofluorescence staining was performed to study the high mobility group protein (HMGB1) / Calreticulin of MCF7 cells with different treatments. Cells were divided into four groups and incubated with: 1, DMEM; 2, TCy5-Ph-2F (1 $\mu \mathrm{M}) ; 3$, TCy5-Ph-3F $(1 \mu \mathrm{M})$ for $4 \mathrm{~h}$. Then the cells were irradiated by $660 \mathrm{~nm}$ LED $\left(5 \mathrm{~mW} / \mathrm{cm}^{-}\right.$ ${ }^{2}, 5$ min). After 4 hours, the cells were washed with pre-cooling PBS, fixed with $4 \%$ paraformaldehyde on $4^{\circ} \mathrm{C}$ for $20 \mathrm{~min}$, and permeated before treated with blocking reagent (10 \% bovine serum in PBS). Then cells were stained with HMGB1 Rabbit Monoclonal Antibody/ Calreticulin Rabbit Monoclonal Antibody overnight at $4^{\circ} \mathrm{C}$. After washed with buffer three times, cells were stained with the Alexa Fluor 488labeled Goat Anti-Rabbit $\operatorname{IgG}(\mathrm{H}+\mathrm{L})$ for $1 \mathrm{~h}$ in the dark and then washed with buffer three times. Finally, the cells incubated with Hoechst 33342. The extracellular levels of HMGB1/Calreticulin in each treated cancer cells were visualized by by confocal fluorescence imaging. For Hoechst 33342, emissions were collected at $430-470 \mathrm{~nm}\left(\lambda_{\mathrm{ex}}\right.$ $=405 \mathrm{~nm}$ ), and for HMGB1 / Calreticulin, emissions were collected at 500-600 nm $\left(\lambda_{\mathrm{ex}}=488 \mathrm{~nm}\right)$.

\section{ATP secretion assay}

$1 \times 10^{5}$ MCF7 cells per well were seeded in 96-well plates. The next day, cell were treated with DMEM, TCy5-Ph-3F $(1 \mu \mathrm{M})$, or with Trolox $(50 \mu \mathrm{M})$ for 1 hour and irradiated with $660 \mathrm{~nm}$ light $\left(5 \mathrm{~min} \times 10 \mathrm{~mW} \mathrm{~cm}^{-2}\right)$. After 10 hours, the conditioned medium was carefully extracted for extracellular ATP measurement by luciferase ATP Assay Kit.

\section{Quantification of apoptosis by flow cytometry}

Apoptosis induced by TCy5 treatment was assessed by double staining MCF7 cells with Annexin V-FITC and propidium iodide. Briefly, MCF7 cells were seeded per well in 6 well plates, and on the third day, the cells were treated with TCy5-Ph-3F $(1 \mu \mathrm{M})$ 
or with $660 \mathrm{~nm}$ light irradiation $\left(5 \mathrm{~mW} / \mathrm{cm}^{-2}, 5 \mathrm{~min}\right) .10$ hours later, the cells were detached using trypsin and exactly $2 \times 10^{5}$ cells per well were counted and resuspended in $300 \mu \mathrm{L}$ of annexin-V binding buffer containing $1 \mu \mathrm{L}$ annexin Annexin V-FITC protein and $1 \mu \mathrm{g} / \mathrm{mL}$ PI. Samples were kept with ice in the dark and analysed immediately on a flow cytometer (Attune ${ }^{\circledR}$ NxT Acoustic Focusing Cytometer A24858).

\section{PDT in the 4T1 tumor bearing mice model}

All procedures were in accordance with the Guide for the Care and Use of Laboratory Animal Resources and the National Research Council, and were approved by the Institutional Animal Care and Use Committee of the NIH. The 4-5 weeks old Balb/c mice were purchased from SPF experimental animal center of Dalian Medical University for transplanting 4T1 cells at a density of $5 \times 10^{6}$ under the subcutaneous of back. When the tumors volume reached $200 \mathrm{~mm}^{3}$, the tumors mice were divided into 6 groups (PBS, PBS + Light, TCy5-Ph-2F, TCy5-Ph-2F + Light, TCy5-Ph-3F, TCy5$\mathrm{Ph}-3 \mathrm{~F}+$ Light, $\mathrm{N}=5)$. The reagent $(50 \mu \mathrm{M}, 100 \mu \mathrm{L})$ was intratumorally injected into the tumor-bearing mice on day 0 . After $2 \mathrm{~h}$ post-injection, tumor region was irradiated with $660 \mathrm{~nm}$ light at a power density of $50 \mathrm{~mW} \mathrm{~cm}^{-2}$ for $20 \mathrm{~min}$. The volume of tumors and the weight of mice were measured by a vernier caliper every other day after treatments. The tumors volume was calculated using the following equation:

$\mathrm{V}=\frac{a \times b^{2}}{2}$

$\mathrm{V}$ represents the tumors volume, $a$ and $b$ represents the longer diameter and the shorter diameter, respectively

\section{In Vivo Biosafety Assay}

The in vivo biosafety assay was performed by using measurement mice weight and H\&E slice histological analysis. After the 14 th day treatment, all mice were sacrificed and the tumor tissues were collected. The main organs including heart, liver, spleen, lung, kidneys were harvested for histological analysis by means of hematoxylin-eosin (H\&E) staining. 


\section{Preparation of TCy5 and the Spectral Data}

a) Preparation of quaternary ammonium salt and condensating agent<smiles>Cc1nc2ccccc2s1</smiles><smiles>CN(C)CCCCc1ccccc1</smiles><smiles>Cc1sc2ccccc2[n+]1Cc1ccccc1Br</smiles>

Scheme S1. Preparation of compounds 1

\section{Synthesis of compound 1: 3-benzyl-2-methylbenzo[d]thiazol-3-ium bromide}

To a stirred solution of 2-Methylbenzothiazole (4 g, $26.8 \mathrm{mmol})$ in acetonitrile (10 mL) was added Benzyl bromide ( $3 \mathrm{~g}, 17.5 \mathrm{mmol})$ at room temperature. The reaction was heated to $60{ }^{\circ} \mathrm{C}$ for 24 hours. Subsequently, the reaction mixture was allowed to cool to room temperature. The precipitate was filtered and dried under vacuo to afford compound 1 as a pale green solid in $95 \%$ yield $(5.5 \mathrm{~g})$.

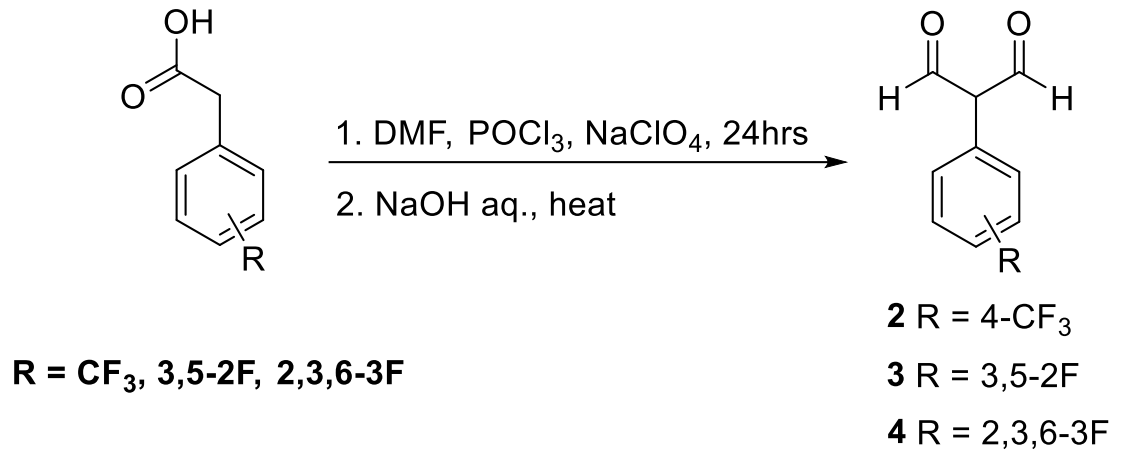

Scheme S2. Preparation of compounds 2-4

\section{Synthesis of compound 2: 2-(4-(trifluoromethyl)phenyl)malonaldehyde}

The title compound was prepared in accordance to the literature. $\mathrm{POCl}_{3}(2.1 \mathrm{~mL}, 22.5$ mmol) was added dropwise to DMF ( $9 \mathrm{~mL})$ at ice-water bath and stirred one hour. After that the mixture was stirred for three hours at room temperature. Subsequently, 2-(4(trifluoromethyl)phenyl)acetic acid ( $1 \mathrm{~g}$ ) was added to the mixture. The clear solution was heated to $90{ }^{\circ} \mathrm{C}$ keeping 4 hours, and then the reaction mixture cooled to room 
temperature. The crushed ice was added to the dark mixture followed by saturated $\mathrm{NaClO}_{4}$ solution. The resulting solid was filtered and carefully washed two times with saturated $\mathrm{NaClO}_{4}$ solution to afford intermediate product, which was used in the next step without further purification. Intermediate product was added to $10 \mathrm{~mL} \mathrm{NaOH}(0.4$ $\mathrm{g}, 10 \mathrm{mmol}$ ) solution and the mixture was heated with stirring at $90{ }^{\circ} \mathrm{C}$ until the mixture was dissolved. The reaction mixture was cooled to room temperature and diluted with $10 \mathrm{~mL}$ water. The solution was acidified to $\mathrm{pH} 2$ with $10 \% \mathrm{HCl}$ solution resulting in the precipitation of the compound 2 (white solid, 0.46 g, $43 \%$ yield). ${ }^{1}$ H NMR (500 $\left.\mathrm{MHz}, \mathrm{CDCl}_{3}\right): \delta 8.68$ (s, 2H), $7.67(\mathrm{~d}, J=8.0 \mathrm{~Hz}, 2 \mathrm{H}), 7.41(\mathrm{~d}, J=8.0 \mathrm{~Hz}, 2 \mathrm{H}) \mathrm{ppm}$; HRMS(ESI): $\mathrm{m} / \mathrm{z}$ calc. for $\left[\mathrm{C}_{10} \mathrm{H}_{6} \mathrm{~F}_{3} \mathrm{O}_{2}\right]^{-} 215.0325$, found $215.0326[\mathrm{M}-\mathrm{H}]^{-}$.

\section{Synthesis of compound 3: 2-(3,5-difluorophenyl)malonaldehyde}

Compound 3 was synthesized according to the synthetic procedure of compound 2.

The result was the brown solid $(0.9 \mathrm{~g}, 84 \%$ yield $) .{ }^{1} \mathbf{H}$ NMR $\left(500 \mathrm{MHz}, \mathrm{DMSO}-\mathrm{d}^{6}\right): \delta$ 8.57 (s, 2H), 7.35-7.25 (m, 2H), 7.14-7.04 (m, 1H) ppm;

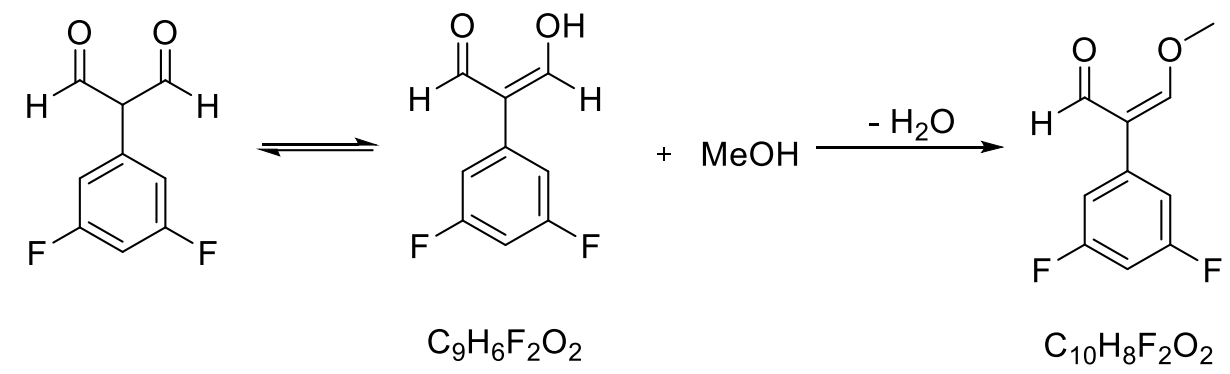

Scheme S3. illustration of the HRMS of compounds 3

HRMS(ESI): m/z calc. for $\left[\mathrm{C}_{10} \mathrm{H}_{9} \mathrm{~F}_{2} \mathrm{O}_{2}\right]^{+}$199.0565, found $199.0560[\mathrm{M}+\mathrm{H}]^{+}$.

\section{Synthesis of compound 4: 2-(2,3,6-trifluorophenyl)malonaldehyde}

Compound 4 was synthesized according to the synthetic procedure of compound 2.

The compound 4 was gotten as white solid (0.65 g, $61 \%$ yield). ${ }^{1} \mathbf{H}$ NMR (500 MHz, $\left.\mathrm{CDCl}_{3}\right): \delta 8.54(\mathrm{~s}, 2 \mathrm{H}), 7.20-7.07(\mathrm{~m}, 1 \mathrm{H}), 7.00-6.86(\mathrm{~m}, 1 \mathrm{H}) \mathrm{ppm} ; \mathrm{HRMS}(\mathrm{ESI}): \mathrm{m} / \mathrm{z}$ calc. for $\left[\mathrm{C}_{9} \mathrm{H}_{4} \mathrm{~F}_{3} \mathrm{O}_{2}\right]^{-}$201.0169, found 201.0163 [M-H]'. 


\section{b) Procedure for the Synthesis of TCy5}

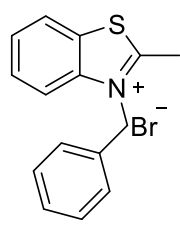

1

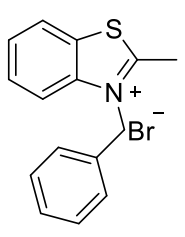

1

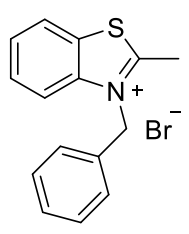

1

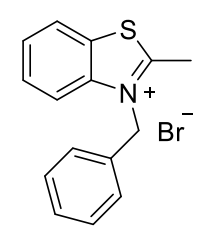

1<smiles>O=CC(C=O)c1ccc(C(F)(F)F)cc1</smiles>

2<smiles>O=CC(C=O)c1cc(F)cc(F)c1</smiles>

3<smiles>O=CC(C=O)c1c(F)ccc(F)c1F</smiles>

4<smiles>C(=C/Nc1ccccc1)\C=N\c1ccccc1</smiles>

5

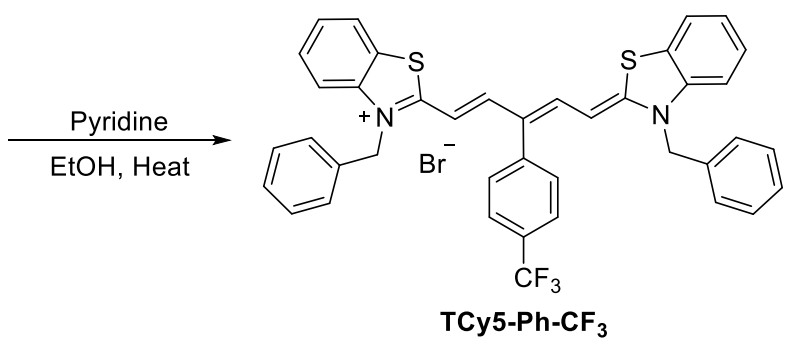

Pyridine
EtOH, Heat<smiles>Fc1cc(F)cc(C(/C=C/c2sc3ccccc3[n+]2Cc2ccccc2)=C/C=C2\Sc3ccccc3N2Cc2ccccc2)c1</smiles>

TCy5-Ph-2F

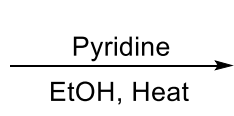<smiles>Fc1ccc(F)c(C(=C\C=C2/Sc3ccccc3N2Cc2ccccc2)/C=C/c2sc3ccccc3[n+]2Cc2ccccc2)c1F</smiles>

TCy5-Ph-3F<smiles>Br[n+]1c(/C=C/C=C/C=C2\Sc3ccccc3N2Cc2ccccc2)sc2ccccc21</smiles>

TCy5-H

Scheme S4. Preparation of compounds TCy5

A stirring mixture of $0.25 \mathrm{mmol}$ condensating agent (1 equiv), $0.625 \mathrm{mmol}$ quaternary ammonium salt (200 mg, 2.5 equiv) in ethyl alcohol $(10 \mathrm{~mL})$ was added three drops of pyridine. The resulting solution was heated to reflux and monitored by TLC analysis. After the yellow intermediate decreases obviously, the solvent was evaporated under reduced pressure to give a residue. The crude material was adsorbed onto silica gel and purified by column chromatography (dichloromethane/methyl alcohol $=20 / 1$ ) to give the corresponding compound TCy5.

\section{TCy5-Ph-CF 3}


The product was obtained as a purple powder with a metallic luster (94 mg, $51 \%$ yield). ${ }^{1} \mathbf{H}$ NMR (500 MHz, DMSO-d $\left.)\right): \delta 8.08(\mathrm{~d}, J=7.5 \mathrm{~Hz}, 2 \mathrm{H}), 7.91(\mathrm{~d}, J=8.5 \mathrm{~Hz}, 2 \mathrm{H})$, $7.89(\mathrm{~d}, J=3.0 \mathrm{~Hz}, 2 \mathrm{H}), 7.74(\mathrm{~d}, J=8.0 \mathrm{~Hz}, 2 \mathrm{H}), 7.57(\mathrm{td}, J=8.5,1.0 \mathrm{~Hz}, 2 \mathrm{H}), 7.45$ (t, $J=8.0 \mathrm{~Hz}, 2 \mathrm{H}), 7.30-7.27(\mathrm{~m}, 6 \mathrm{H}), 7.13(\mathrm{~d}, J=8.0 \mathrm{~Hz}, 2 \mathrm{H}), 6.97(\mathrm{~d}, J=7.0 \mathrm{~Hz}, 4 \mathrm{H})$, 5.78 (d, $J=13.5 \mathrm{~Hz}, 2 \mathrm{H}), 5.44$ (s, 4H) ppm; ${ }^{13} \mathrm{C}$ NMR (125 MHz, DMSO-d $)$ : $\delta 164.62$, $141.80,134.59,128.84,128.26,128.17,128.02$, 126.69, 125.41, 125.27, 113.58, 99.24, 49.27, $22.05 \mathrm{ppm} ; \mathrm{HRMS}(\mathrm{ESI}): \mathrm{m} / \mathrm{z}$ calc. for $\left[\mathrm{C}_{40} \mathrm{H}_{30} \mathrm{~F}_{3} \mathrm{~N}_{2} \mathrm{~S}_{2}\right]^{+}$659.1797, found $659.1799[\mathrm{M}-\mathrm{Br}]^{+}$.

\section{TCy5-Ph-2F}

The product was obtained as a purple powder (73 mg, $41 \%$ yield). ${ }^{1} \mathbf{H}$ NMR $(500 \mathrm{MHz}$, DMSO- $\left.d_{6}\right): \delta 8.09$ (d, $\left.J=8.0 \mathrm{~Hz}, 2 \mathrm{H}\right), 7.93-7.85(\mathrm{~m}, 4 \mathrm{H}), 7.58(\mathrm{t}, J=7.0 \mathrm{~Hz}, 2 \mathrm{H}), 7.45$ (t, $J=7.5 \mathrm{~Hz}, 2 \mathrm{H}), 7.37-7.33(\mathrm{~m}, 3 \mathrm{H}), 7.32-7.28(\mathrm{~m}, 6 \mathrm{H}), 7.05(\mathrm{~d}, J=4.0 \mathrm{~Hz}, 4 \mathrm{H}), 6.63$ $(\mathrm{d}, J=5.0 \mathrm{~Hz}, 2 \mathrm{H}), 5.85$ (d, J= 13.0 Hz, 2H), 5.49 (s, 4H) ppm; ${ }^{13} \mathbf{C}$ NMR (125 MHz, DMSO- $\left.d_{6}\right): \delta 171.96,164.74,141.79,134.64,128.89,128.28,128.04,126.79,125.41$, 125.28, 123.35, 113.65, 99.18, 49.19, $21.02 \mathrm{ppm} ; \mathrm{HRMS}(\mathrm{ESI}): \mathrm{m} / \mathrm{z}$ calc. for $\left[\mathrm{C}_{39} \mathrm{H}_{29} \mathrm{~F}_{2} \mathrm{~N}_{2} \mathrm{~S}_{2}\right]^{+}$627.1735, found 627.1731 [M-Br] $]^{+}$

\section{TCy5-Ph-3F}

The product was obtained as a purple powder (116 mg, $64 \%$ yield). ${ }^{1}$ H NMR (500 MHz, DMSO-d6): $\delta 8.09$ (d, $J=8.0 \mathrm{~Hz}, 2 \mathrm{H}), 8.05(\mathrm{~d}, J=13.5 \mathrm{~Hz}, 2 \mathrm{H}), 7.90(\mathrm{~d}, J=8.5$ $\mathrm{Hz}, 2 \mathrm{H}), 7.58$ (t, J= 7.5 Hz, 2H), 7.46 (t, J=7.5 Hz, 2H), 7.36-7.26 (m, 8H), 7.05-6.99 $(\mathrm{m}, 4 \mathrm{H}), 5.73(\mathrm{~d}, J=13.0 \mathrm{~Hz}, 2 \mathrm{H}), 5.59-5.44(\mathrm{~m}, 4 \mathrm{H}), \mathrm{ppm} ;{ }^{13} \mathbf{C}$ NMR $(125 \mathrm{MHz}$, DMSO- $\left.d_{6}\right): \delta 171.96,165.15,141.75,134.62,128.88,128.27,128.01,126.79,125.49$, 125.36, 123.37, 113.79, 98.97, 49.19, $21.02 \mathrm{ppm} ; \mathbf{H R M S ( E S I ) : ~ m / z ~ c a l c . ~ f o r ~}$ $\left[\mathrm{C}_{39} \mathrm{H}_{30} \mathrm{~N}_{3} \mathrm{O}_{2} \mathrm{~S}_{2}\right]^{+}$645.1641, found 645.1645 [M-Br] $]^{+}$.

\section{TCy5-H}

Both of condensating agent 5 ( $0.5 \mathrm{mmol}, 1$ equiv), ${ }^{4}$ compound 1 ( $1 \mathrm{mmol}, 2.5$ equiv) and sodium acetate $(0.1 \mathrm{mmol}, 0.2$ equiv) were dissolved in acetic oxide $(10 \mathrm{~mL})$. The resulting solution was stirred in the room temperature and monitored by TLC analysis. After the yellow intermediate almost disappeared, the solvent was evaporated under reduced pressure to give a residue. Then, the residue was dissolved in $100 \mathrm{~mL} \mathrm{DCM}$, 
and organic layer was washed with saline and dried with anhydrous $\mathrm{Na}_{2} \mathrm{SO}_{4}$. Finally, the organic layer was evaporated to dryness and the crude material was adsorbed onto silica gel and purified by column chromatography (dichloromethane/methyl alcohol = 20/1) give the compound TCy5-H.

The product was obtained as a purple powder with a metallic luster $(241 \mathrm{mg}, 81 \%$ yield). ${ }^{1}$ H NMR (500 MHz, DMSO- $\left.d_{6}\right): \delta 8.09(\mathrm{~d}, J=8.0 \mathrm{~Hz}, 2 \mathrm{H}), 8.05(\mathrm{~d}, J=13.5 \mathrm{~Hz}, 2 \mathrm{H})$, $7.90(\mathrm{~d}, J=8.5 \mathrm{~Hz}, 2 \mathrm{H}), 7.58(\mathrm{t}, J=7.5 \mathrm{~Hz}, 2 \mathrm{H}), 7.46(\mathrm{t}, J=7.5 \mathrm{~Hz}, 2 \mathrm{H}), 7.36-7.26(\mathrm{~m}$, 8H), 7.05-6.99 (m, 4H), 5.73 (d, $J=13.0 \mathrm{~Hz}, 2 \mathrm{H}), 5.59-5.44$ (m, 4H), ppm; ${ }^{13} \mathbf{C}$ NMR (125 MHz, DMSO-d6): $\delta$ 171.96, 165.15, 141.75, 134.62, 128.88, 128.27, 128.01, 126.79, 125.49, 125.36, 123.37, 113.79, 98.97, 49.19, 21.02 ppm; HRMS(ESI): m/z calc. for $\left[\mathrm{C}_{39} \mathrm{H}_{30} \mathrm{~N}_{3} \mathrm{O}_{2} \mathrm{~S}_{2}\right]^{+}$645.1641, found $645.1645[\mathrm{M}-\mathrm{Br}]^{+}$. 


\section{5. ${ }^{1} \mathrm{H}$ NMR, ${ }^{13} \mathrm{C}$ NMR spectrogram and HRMS data}

\section{TCy5-Ph-CF 3}
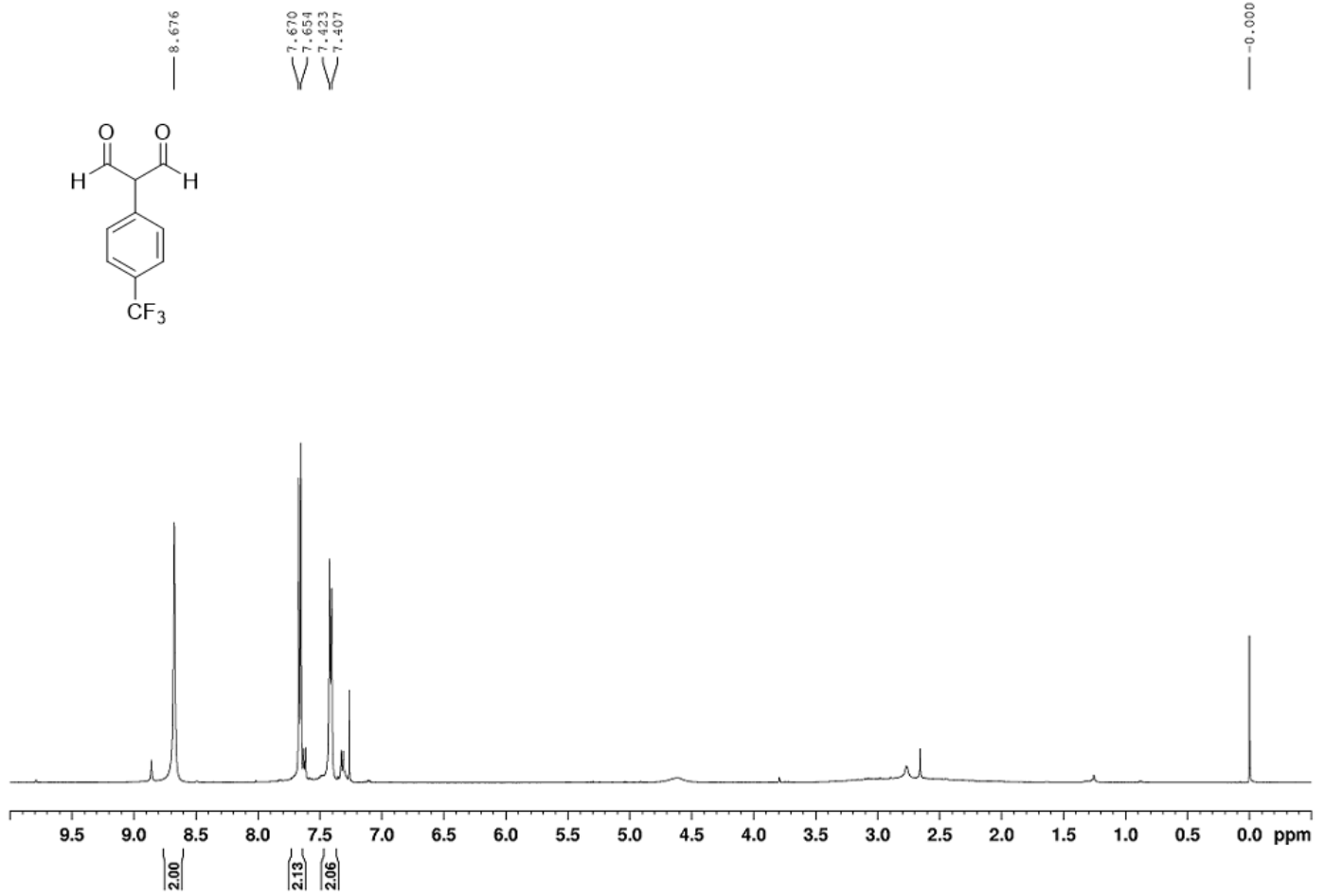

MH-216

202007310119 (0.398) AM2 (Ar,20000.0,554.26,0.00,LS 10); Cm (19) 1: TOF MS ES-

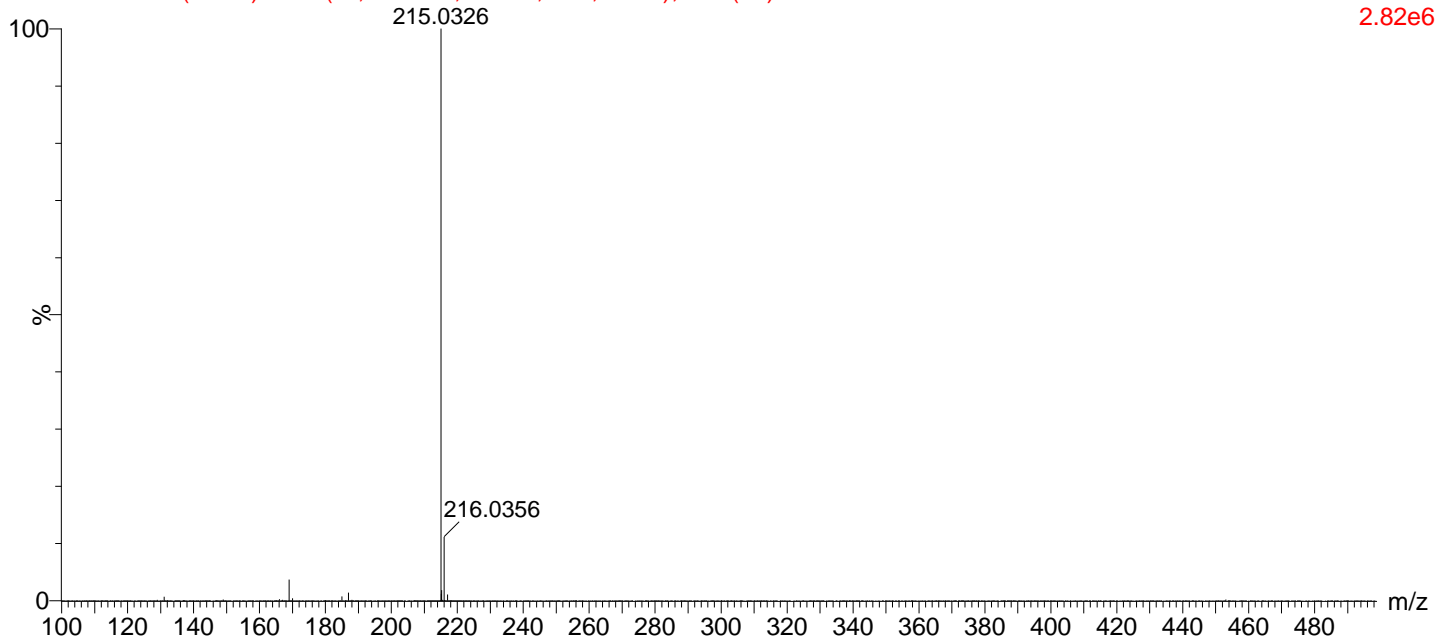




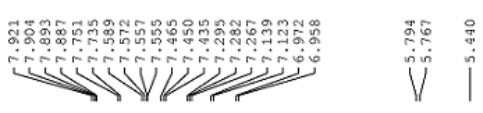

(c)

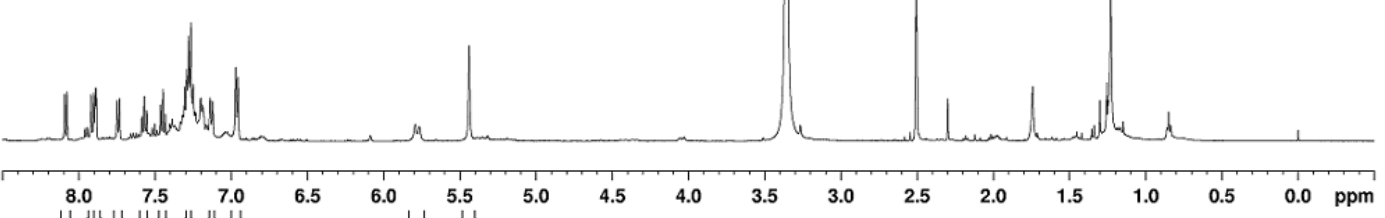

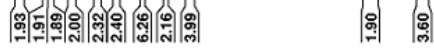
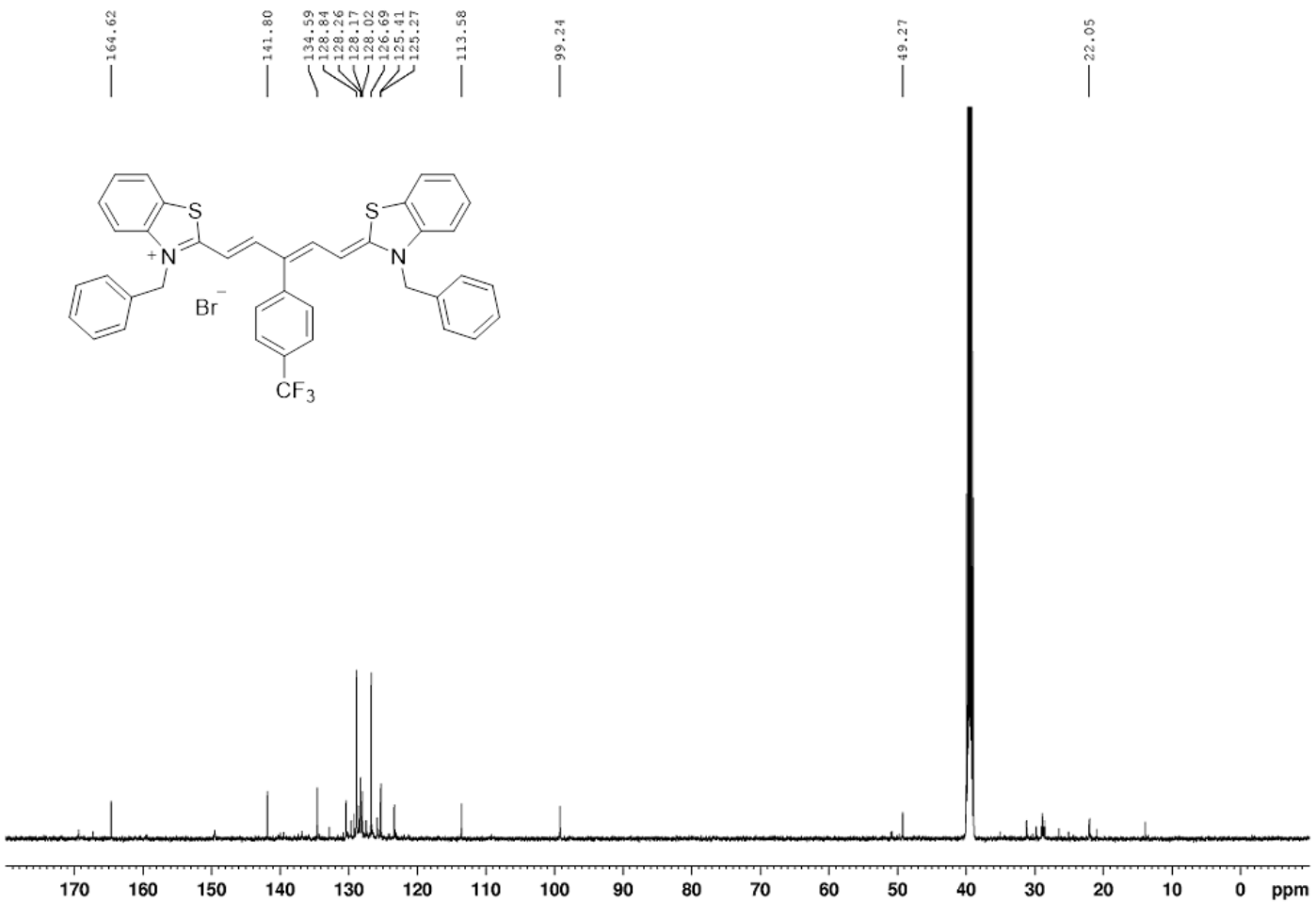
MH-659

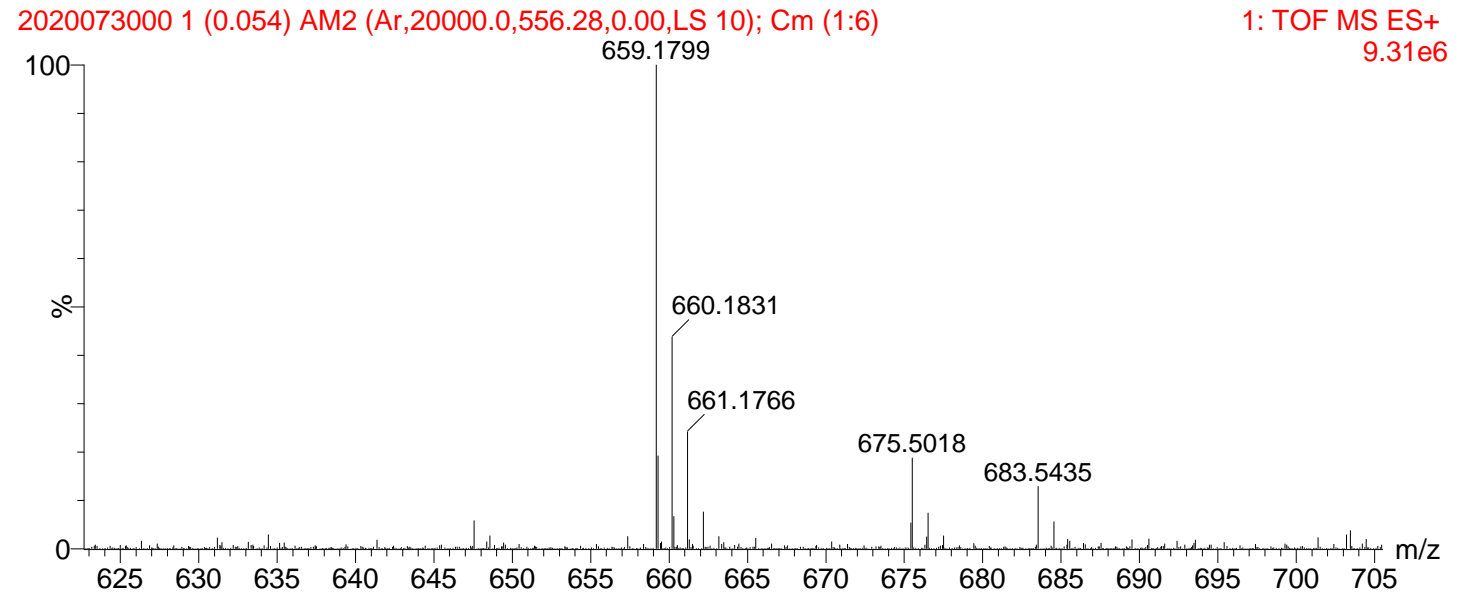


TCy5-Ph-2F

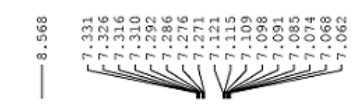

i̊
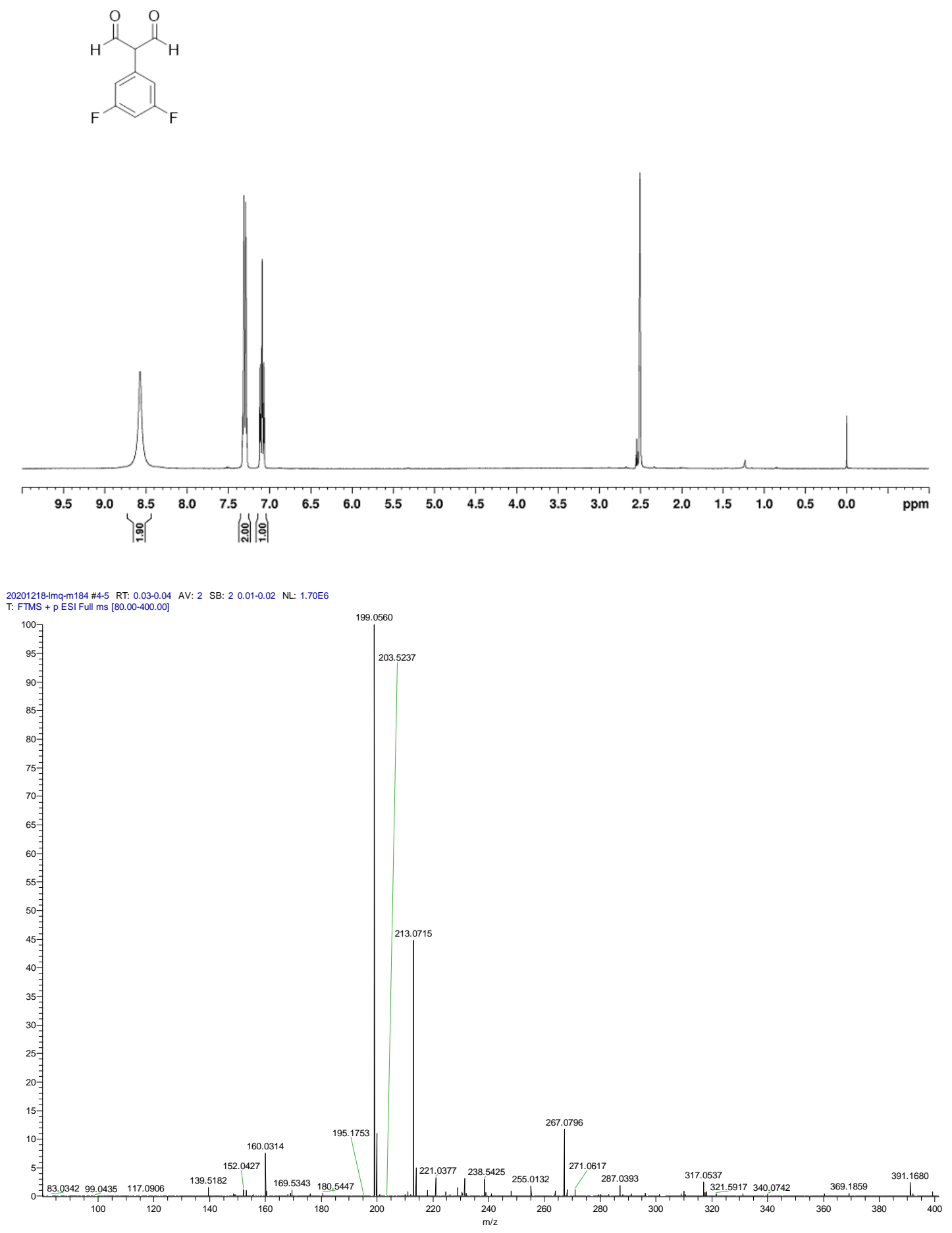

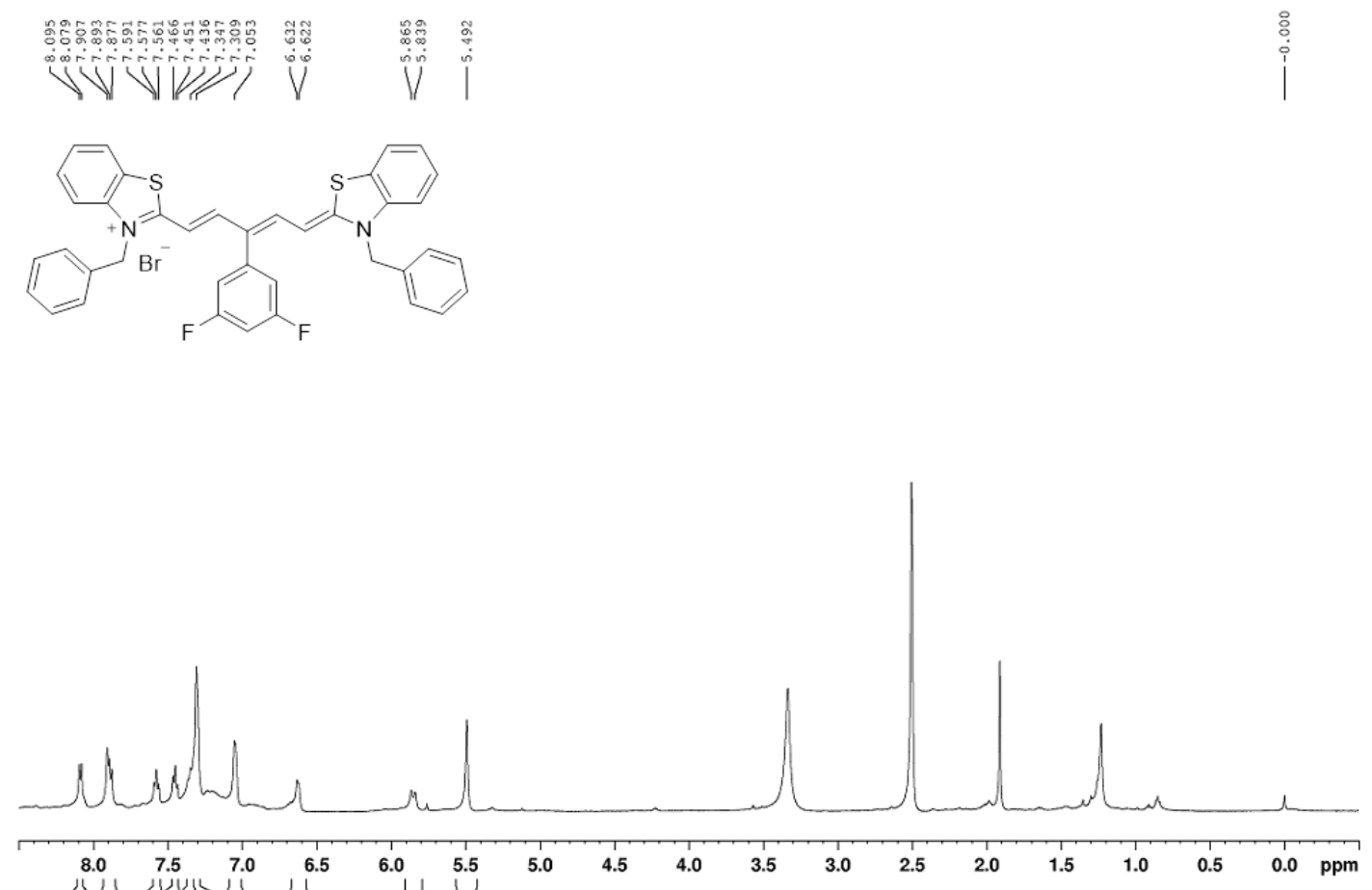

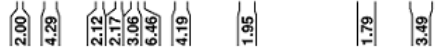
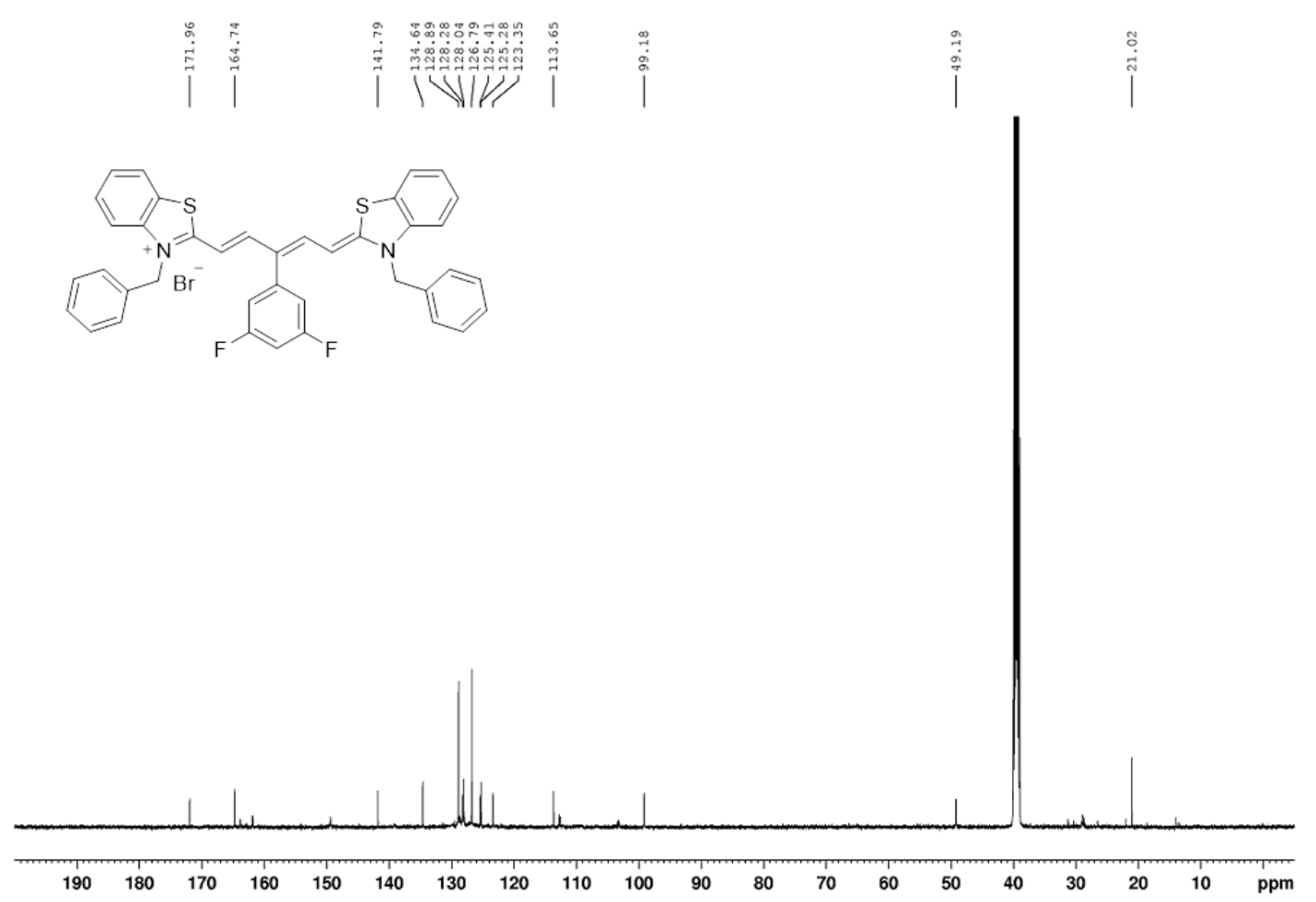


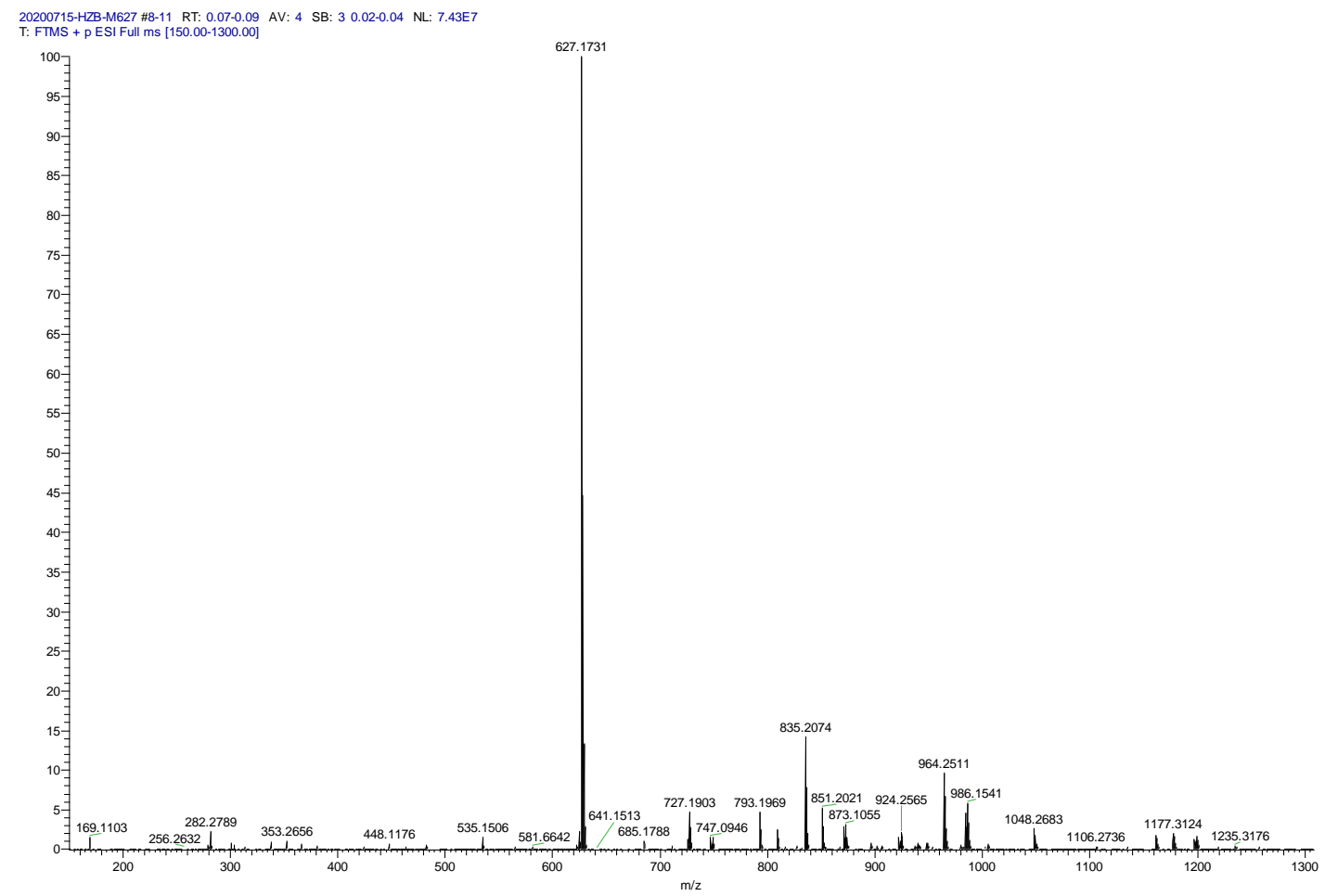




\section{TCy5-Ph-3F}
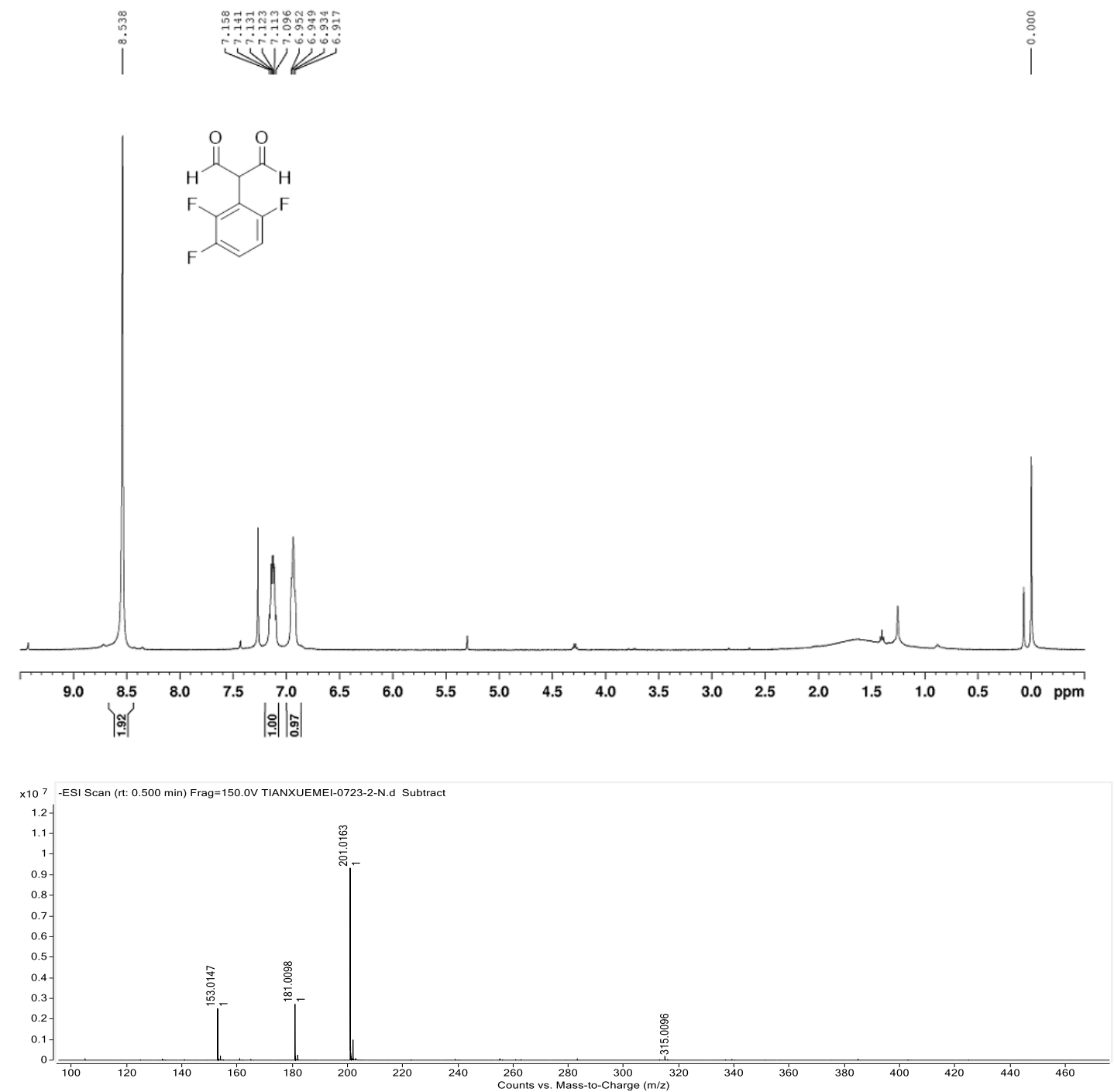


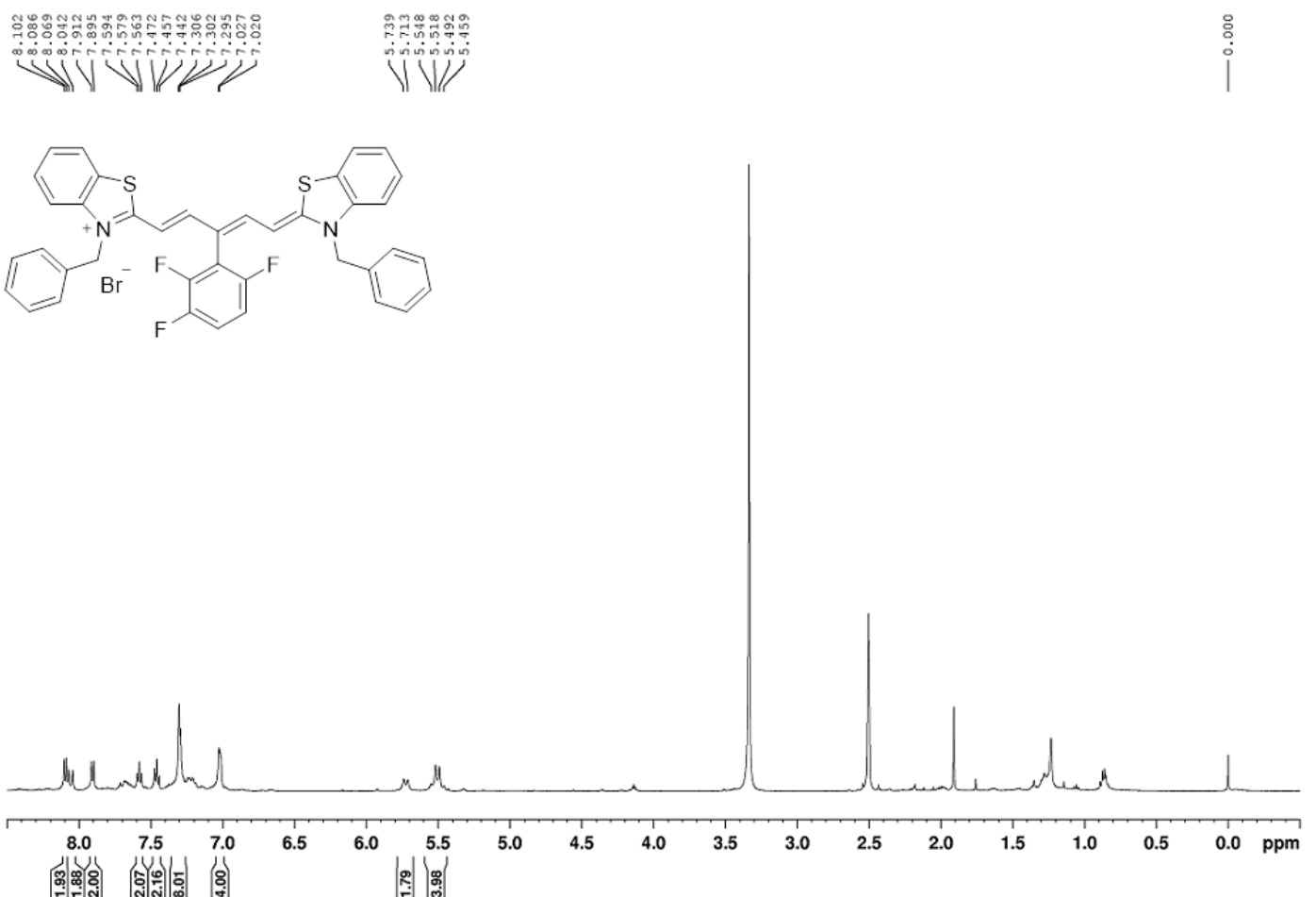

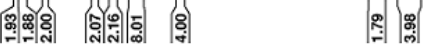
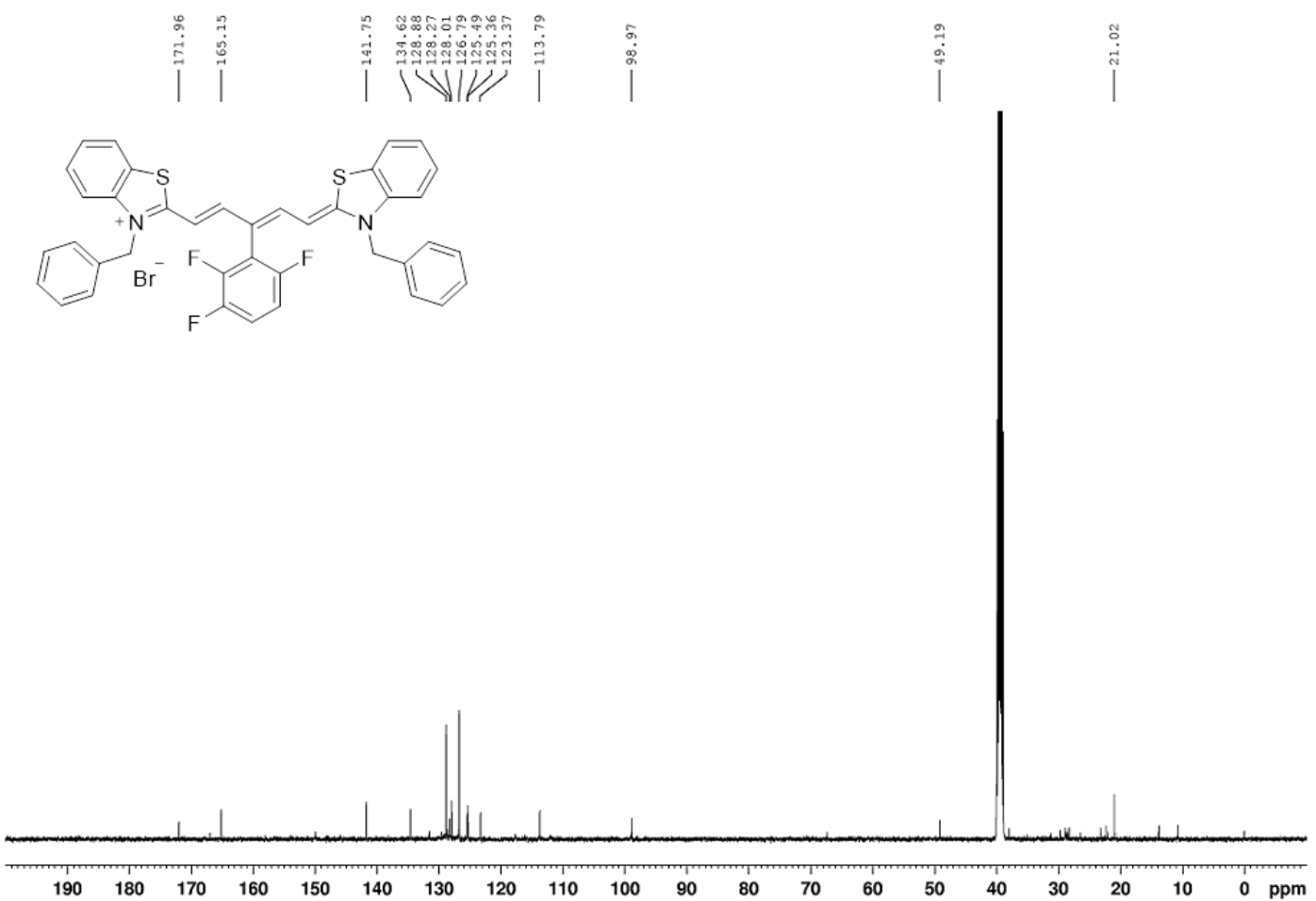


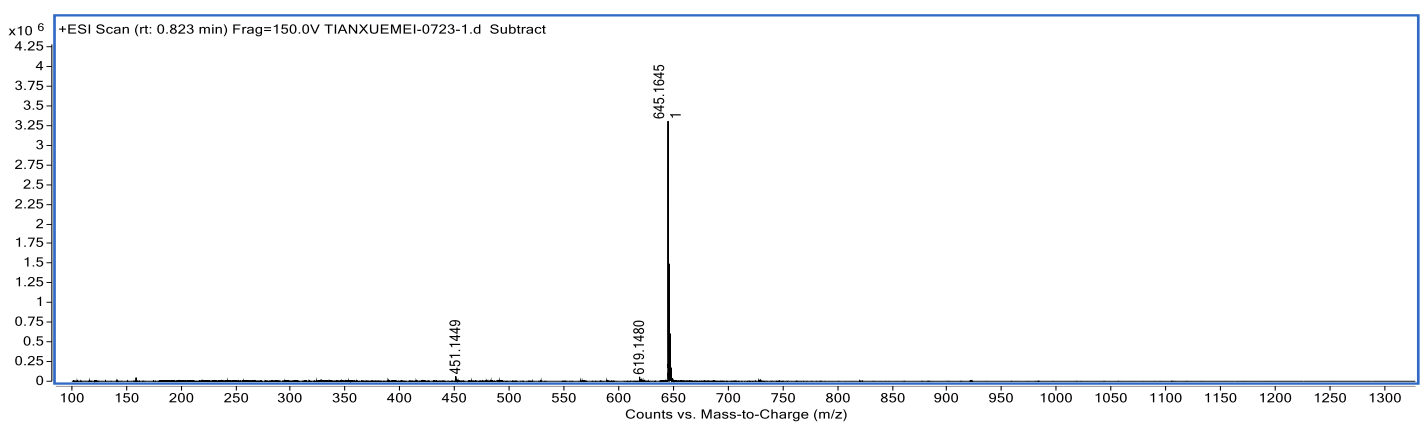


TCy5-H

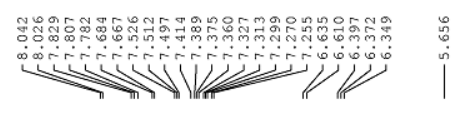

i
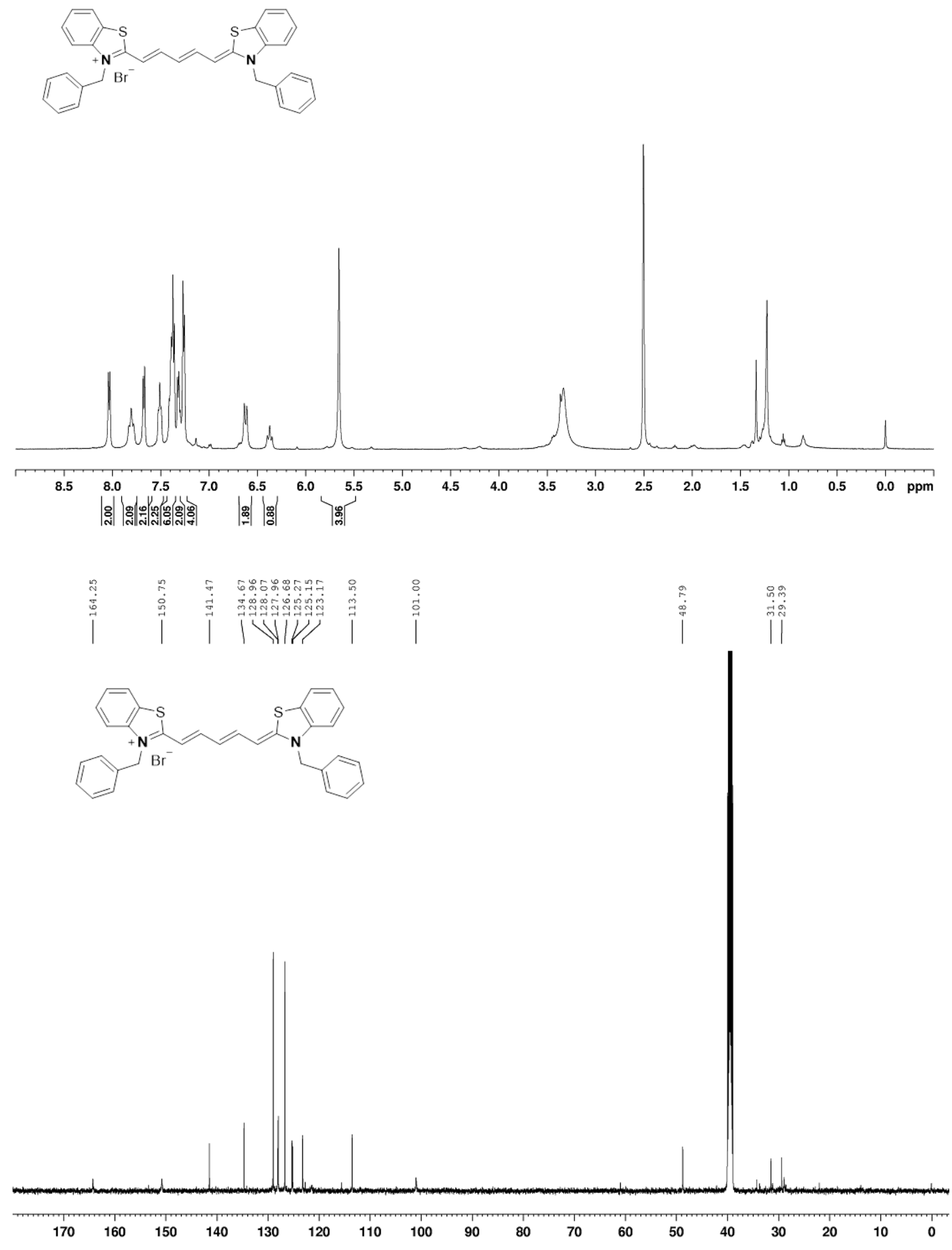
20200716-MH-M515 \#6 RT: 0.06 AV: 1 NL: 6.64E7
T. FTMS + p ESI Full ms [120.00-1000.00]

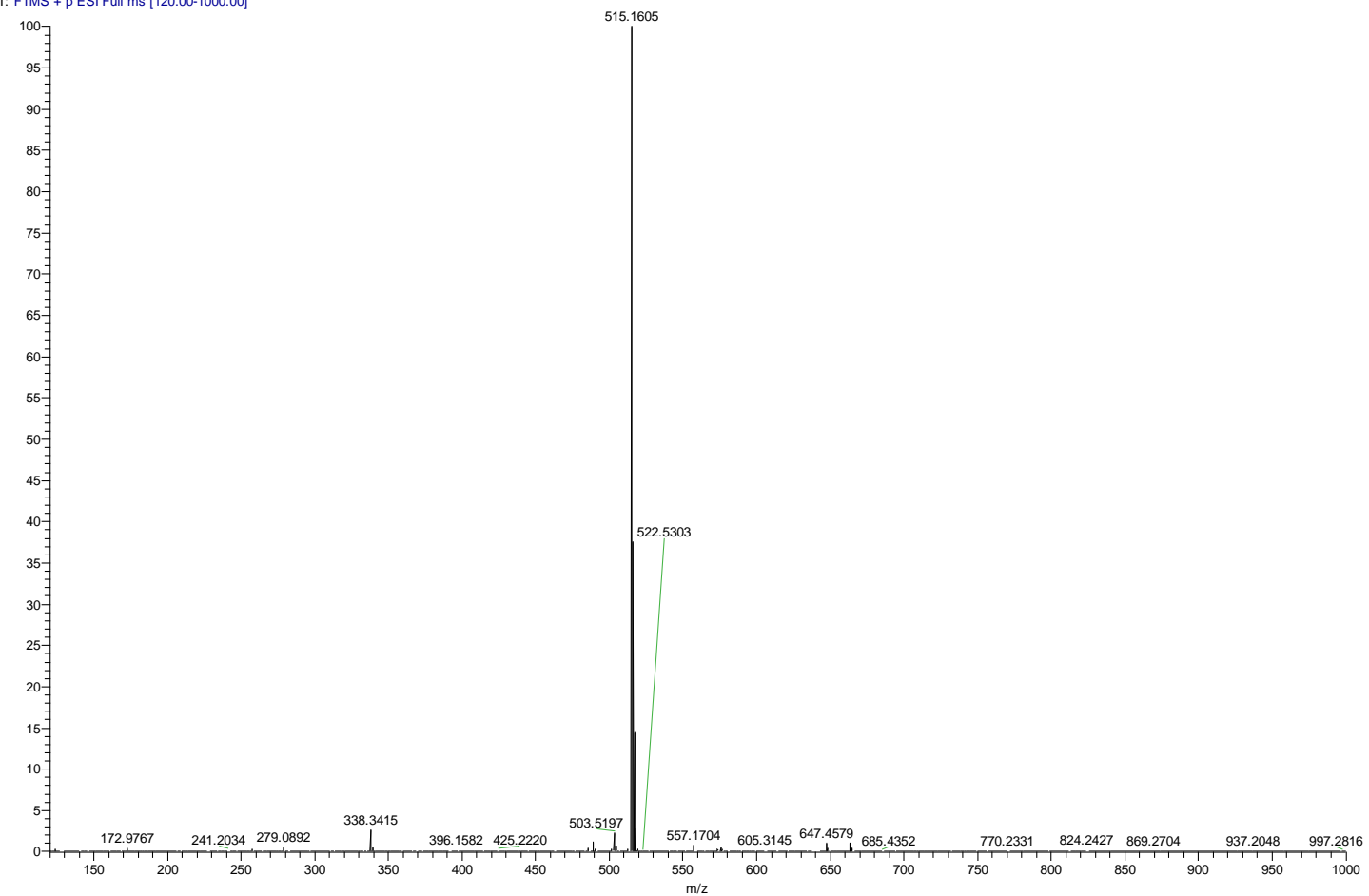




\section{Reference}

(1) Gao, Y.; Wang, X.; He, X.; He, Z.; Yang, X.; Tian, S.; Meng, F.; Ding, D.; Luo, L.; Tang, B. Z., A Dual-Functional Photosensitizer for Ultraefficient Photodynamic Therapy and Synchronous Anticancer Efficacy Monitoring. Adv. Funct. Mater. 2019, 29 (32), 1902673.

(2) Nhan, D. T.; Hien, N. K.; Van Duc, H.; Nhung, N. T. A.; Trung, N. T.; Van, D. U.; Shin, W. S.; Kim, J. S.; Quang, D. T., A hemicyanine complex for the detection of thiol biomolecules by fluorescence. Dyes and Pigments 2016, 131, 301-306.

(3) Zhou, L. C.; Zhao, G.; Liu, J.; Han, K.; Wu, Y. K.; Peng, X. J.; Sun, M., The charge transfer mechanism and spectral properties of a near-infrared heptamethine cyanine dye in alcoholic and aprotic solvents. Journal of Photochemistry and Photobiology A-chemistry 2007, 187 (2), 305-310.

(4) Brun, M. A.; Tan, K.-T.; Nakata, E.; Hinner, M. J.; Johnsson, K., Semisynthetic Fluorescent Sensor Proteins Based on Self-Labeling Protein Tags. J. Am. Chem. Soc. 2009, 131 (16), 5873-5884. 